\title{
A política fiscal no contexto da financeirização: teoria insuficiente e indicadores inadequados *
}

\author{
Flávio Arantes ** \\ Geraldo Biasoto Junior ***
}

\begin{abstract}
Resumo
O trabalho se propõe a problematizar a concepção de política fiscal no pensamento dominante em macroeconomia. A crítica enfoca a insuficiência dessa corrente em captar as relações entre o Estado e o capitalismo financeirizado e a inadequação dos indicadores utilizados para a avaliação da política fiscal. Num padrão de acumulação em que a gestão de ativos e a valorização da riqueza financeira dominam os movimentos dos fluxos econômicos, a política fiscal, muito além de lidar com receitas tributárias e despesas reais, se depara com a gestão dos estoques, seus movimentos e remunerações. Usando o caso da economia brasileira, mostra-se que as ações de natureza financeira e patrimonial que o Estado é compelido a realizar impactam o resultado fiscal de maneira mais significativa que os efeitos das receitas e despesas públicas, de maneira que, os indicadores-síntese utilizados, não expressam a dinâmica real das contas públicas e seu impacto sobre a economia.
\end{abstract}

Palavras-chave: Política fiscal - Brasil; Novo consenso macroeconômico, Financeirização.

\section{Abstract \\ Fiscal policy in the context of financialization: insufficient theory and inadequate indicators}

The paper queries the conception of fiscal policy in mainstream macroeconomics. The critics focus on the insufficiency of this approach to capture the relations established between the state and financialized capitalism and on the inadequacy of the indicators used to assess fiscal policy. In a pattern of capital accumulation in which the asset management and the financial wealth valuation overcome economic flows, fiscal policy, far beyond dealing with tax collection and real spending, must manage the financial stocks and their yields. Using the Brazilian economy as the case study, the paper shows that the financial and patrimonial management of the federal state is compelled to have greater impacts on fiscal balance than those related to public spending and collection. In a sense, the chosen fiscal indicators do not express the real dynamics of fiscal accounts and their impacts on the economy.

Keywords: Fiscal policy - Brazil; New macroeconomic consensus; Financialization.

JEL G32.

\section{Introdução}

O pensamento dominante atual em macroeconomia, o Novo Consenso Macroeconômico (NCM), coloca a ênfase da discussão sobre a política fiscal na questão da sustentabilidade da dívida pública e no tamanho do superávit primário

* Artigo recebido em 5 de abril de 2017 e aprovado em 18 de setembro de 2017.

** Doutorando em Economia do Instituto de Economia da Universidade Estadual de Campinas (Unicamp), Campinas, SP, Brasil. E-mail: flarantes@gmail.com.

${ }^{* * * *}$ Professor do Instituto de Economia da Unicamp, Campinas, SP, Brasil. E-mail: biasoto@unicamp.br. 
necessário para garantir-lhe uma dinâmica sustentável no tempo. A adoção de ambos como principais sinalizadores do comportamento fiscal serviu ao propósito de obscurecer o verdadeiro sentido das relações econômicas que estão por trás dos números.

A supremacia do superávit primário como medida e meta de política econômica esvaziou a discussão sobre a atuação fiscal do Estado na dinâmica da economia. É como se pouco importasse se a meta fosse alcançada com carga tributária de $10 \%$ ou $30 \%$ do PIB ou se os gastos se concentrassem no pagamento de salários ou de investimentos em infraestrutura.

O mesmo problema aparece no tratamento das questões de endividamento público. A relação dívida/PIB surge como elemento de síntese, com poder explicativo absoluto, mas questões teóricas decisivas são ignoradas por aqueles que defendem a sustentabilidade da dívida como valor supremo. Primeiro, a relação entre estoques e fluxos está sujeita a muitos condicionantes que não têm sido levados em consideração no pensamento dominante. Segundo, ter por base uma estrutura de passivos sem dimensionar e integrar os agentes possuidores dos respectivos ativos à análise, pouco esclarece sobre a verdadeira situação das contas públicas e sobre a atuação do Estado.

A crise de 2008 apontou a verdadeira dimensão e significado da política fiscal na economia capitalista. Mostrou, sobretudo, como a política fiscal é executada em um mundo dominado pela financeirização e seu papel na gestão de ativos e passivos do conjunto do sistema. Ademais, deixou transparentes os limites de se pensar essa política com base simplesmente no uso dos atuais indicadores de déficit e dívida.

A proposta do artigo é, a partir de dados da economia brasileira, questionar a política fiscal no NCM e o emprego dos indicadores fiscais tradicionais, por sua incapacidade de refletir aspectos relevantes da dinâmica das contas públicas. $\mathrm{O}$ uso desses indicadores é ainda mais problemático na fase atual, financeirizada, do capitalismo, cuja dinâmica deixou de se basear em fluxos e se sustenta na gestão de ativos e na valorização da riqueza financeira.

Com esse objetivo o artigo é dividido em 4 seções, além dessa introdução. Na seção 1 resgatamos o modelo do NCM e a lógica que impõe o uso dos indicadores fiscais como meta a ser alcançada e as implicações sobre a condução da política fiscal. Argumentamos que, no NCM, a política fiscal ocupa lugar subordinado e de âncora das principais variáveis macroeconômicas. Na seção 2 , fazemos a crítica à lógica do NCM segundo a perspectiva de uma economia monetária da produção abordagem que será utilizada no restante do artigo. Chamamos a atenção para um entendimento mais amplo das finanças públicas, mostrando o papel do Estado de garantir a gestão da riqueza em suas diversas formas e mercados. Argumentamos 
que o Estado é instado a realizar políticas de gestão do estoque de riquezas e dos ativos privados e a assumir responsabilidades sobre sua valorização. Por essas razões, suas tarefas no capitalismo financeirizado são muito mais complexas e dispendiosas do que aquelas vigentes quando suas ações se limitavam a gerir os fluxos de renda e produção. Na seção 3, usamos os dados da economia brasileira para justificar a abordagem aqui adotada, identificando as principais ações de natureza financeira e patrimonial que impactam o resultado das contas públicas, de modo a mostrar que em uma economia financeirizada, a gestão fiscal está longe de refletir apenas os efeitos das receitas e despesas públicas. $\mathrm{Na}$ sequência, tecemos algumas considerações finais.

\section{A política fiscal no pensamento dominante e os indicadores fiscais}

Há algumas décadas não era difícil entender a política fiscal e os resultados apresentados nos indicadores usuais. Em um capitalismo regulado ${ }^{3}$, o comportamento fiscal estava diretamente relacionado aos fluxos de receitas e despesas, o que exigia refletir sobre a dinâmica do sistema tributário e das principais funções do setor público. O controle da política fiscal vinculava-se às condições de gestão orçamentária e os níveis de endividamento público e de gastos com juros não despertavam maiores preocupações.

A dinâmica econômica, baseada fundamentalmente em fluxos, não se confrontava com grandes estoques e o uso de instrumentos financeiros sofisticados era restrito e pouco impactava as contas públicas, deixando-a livre para tratar das questões relativas à distribuição dos gastos e ao movimento da arrecadação. As fronteiras de identificação do campo fiscal eram mais nítidas e, teoricamente, trabalhava-se com conceitos mais restritos de contas públicas.

A preocupação dos teóricos da síntese neoclássica e dos monetaristas na aferição do resultado fiscal atendia à busca de captação do impacto das contas públicas sobre a demanda agregada, por se acreditar que a presença do Estado deficitário poderia resultar em processos inflacionários, gerados, no entender dos monetaristas (Friedman, 1948; Friedman e Heller, 1969), pela expansão monetária e crescente demanda de bens e, na visão da síntese, pelo desequilíbrio entre oferta e demanda agregada.

O uso do conceito de Necessidade de Financiamento do Setor Público (NFSP), que expressa de maneira relativamente clara e simples o déficit público consolidado, serviu de suporte ao modelo monetário de ajuste do balanço de pagamentos (BP) que embasou as políticas de ajuste do Fundo Monetário Internacional, implementadas como parte dos acordos realizados no período da crise da dívida externa nos anos 1980 (Biasoto, 1995). O déficit público era visto como

(3) Ver Belluzzo (1995). 
determinante do excesso de crédito interno líquido, responsável por ampliar a demanda agregada e gerar os problemas de BP (Bacha, 1983). Assim, a redução do déficit em conta corrente dependia do sucesso em fazer o ajuste fiscal, já que o controle do déficit público implicava cortes do crédito líquido da autoridade monetária e redução da demanda, com queda das importações.

Nessa discussão, portanto, a posição corrente das contas públicas era o foco da atenção e o conceito de NFSP medida suficiente para indicar a situação fiscal de determinado país. Controlar a NFSP significava controlar o impacto do setor público na economia, pois, dada a relação entre a política fiscal e a política monetária, o excesso de demanda agregada, seus impactos no BP, na inflação e no crowding out dos gastos privados seriam distorções evitadas.

A mudança do enfoque teórico dominante, com a presença dos novos clássicos e dos novos keynesianos, resultando no que veio a ser conhecido como o Novo Consenso Macroeconômico ${ }^{4}$ (NCM), trouxe novos desdobramentos ao debate sobre os impactos da política fiscal na economia e no desenvolvimento dos indicadores. Em paralelo a esse movimento teórico, o processo de liberalização dos mercados globais e a livre movimentação de capitais após o fim do acordo de Bretton Woods, reforçam a defesa de que os países devem estabelecer condições macroeconômicas estáveis para entrarem no circuito de valorização internacional do capital (Lopreato, 2004; 2006), juntamente com a necessidade de indicadores simples, de amplo entendimento e que permitem comparações entre as diferentes economias.

Na perspectiva teórica, a partir da "crítica de Lucas" e da literatura sobre consistência temporal ("time-consistency"), ganharam força na corrente dominante as possíveis vantagens da adoção de regras na condução da política monetária ${ }^{5}$ e do abandono das ações específicas de administração da demanda agregada, com especial rejeição às medidas fiscais.

O NCM acatou a ideia de que os dirigentes econômicos devem estar comprometidos com as "regras do jogo" ou com "o" regime de política econômica capaz de, a cada período, validar as expectativas dos agentes e garantir os resultados macroeconômicos desejados (Lopreato, 2006; Santos, 2011). O modelo do NCM

(4) Goodfriend e King (1997) é o primeiro trabalho a apontar uma convergência metodológica e de proposições de política macroeconômica no mainstream, no que denominaram de Nova Síntese Neoclássica. Para os autores, a combinação dos pressupostos de otimização intertemporal e de expectativas racionais nos modelos macroeconômicos dinâmicos, dos novos clássicos, com a concorrência imperfeita e as rigidezes de preços e salários, dos novos keynesianos, dá a síntese do debate, implicando em um modelo de atuação governamental com regras de atuação para as políticas macroeconômicas. O modelo básico que passa a expressar a convergência é apresentado nas suas primeiras versões em Clarida et al. (1999); McCallum (2001); Meyer (2001) e Woodford (2003). Já Woodford (2008) sintetiza em grandes linhas o NCM.

(5) A ideia, presente desde Friedman (1948), se intensifica no atual mainstream a partir das discussões trazidas por Kydland e Prescott (1977); Barro e Gordon (1983) e Taylor (1993). 
sacramentou a política monetária como instrumento chave de ajuste macroeconômico e colocou a política fiscal em papel subordinado, mas responsável pela estabilidade de longo prazo.

No modelo ${ }^{6}$ do NCM, a política fiscal é captada por uma constante ou um choque exógeno na curva IS, uma vez que essa política não tem qualquer papel no ajuste macroeconômico, nessa visão ${ }^{7}$. Uma série de argumentos teóricos e empíricos levaram os autores do pensamento dominante a rejeitarem o papel da política fiscal enquanto instrumento de ajuste ${ }^{8}$ e uma análise detalhada pode ser encontrada em Santos (2011). Importante apenas lembrar que tais argumentos, muitas vezes alimentados por uma indisposição geral (ideológica e política) do mainstream em relação à interferência do Estado na economia, abrangem as questões das demoras de implementação das políticas ("implementation lags"), levantadas desde Friedman (1968), e das muitas variantes de crowding out dos gastos privados pelo gasto público, culminando na Teoria da Equivalência Ricardiana (Barro, 1974).

O NCM herda a discussão de ineficiência e passa a atribuir à política fiscal o papel de garantir os fundamentos da economia (Wren-Lewis, 2000; Lopreato, 2004). Isso significa manter as contas públicas de modo a permitir a eficiência da política monetária - livre de dominância fiscal (Sargent; Wallace, 1981) ${ }^{9}$ - no controle da inflação. A preocupação do NCM para com a política fiscal passa a ser apenas com a previsibilidade e sustentabilidade das contas públicas, pois uma trajetória previsível e sustentável para as variáveis fiscais ${ }^{10}$ permite que os agentes econômicos validem suas expectativas e o sistema atinja o equilíbrio geral.

Essa discussão rebate na definição dos indicadores usados para sinalizar as contas públicas. O conceito de NFSP permanece em uso, relevante para indicar as condições conjunturais do setor público, principalmente a sua parcela primária, mas a trajetória fiscal prospectiva passa a ser avaliada pelo conceito de sustentabilidade do endividamento público, captado pela relação dívida/PIB.

(6) Amplamente conhecido na literatura, o modelo básico do NCM, com uma curva IS, uma curva de Phillips e uma regra de Taylor tem como objetivos macroeconômicos a determinação do produto no seu nível potencial e da inflação na meta. Para isso, o ajuste ocorre via taxa de juros nominal a cargo do Banco Central. O modelo usado como referência aqui é o mesmo de Arestis e Sawyer (2002); Arestis (2007); Carlin e Soskice (2006); Tcherneva (2008) e Fontana (2009).

(7) Como apontam Arestis e Sawyer (2002, 2003); Tcherneva (2008); Fontana (2009), entre outros.

(8) Ver Blinder (2004), Solow (2005) e Forder (2007).

(9) Como dito anteriormente, no modelo básico do NCM a política fiscal é pré-determinada (uma constante) ou representa um choque exógeno. É preciso frisar que é pressuposto que a política monetária não reaja à política fiscal. Na maior parte da literatura mainstream que analisa as interações entre as duas políticas e em que a inflação é objetivo macroeconômico, a política fiscal sempre reage à política monetária e não o contrário. Ver, a respeito, Kirsanova et al. (2005), Leeper (1991) e Leeper e Walker (2013).

(10) Tais como a arrecadação e os programas de gastos, a emissão de títulos, o financiamento externo e a dívida pública. 
Mesmo não estando presente no modelo básico do $\mathrm{NCM}^{11}$, implicitamente, a dívida é sustentável se o governo cumpre a restrição orçamentária necessária para garantir sua solvência e evitar seu crescimento explosivo:

$$
D=G-T+i B=\Delta B+\Delta H
$$

onde $D$ é o déficit, $G$ os gastos públicos, $T$ a arrecadação tributária, $B$ o estoque de dívida, $i$ a taxa de juros nominal e $H$ a senhoriagem.

A equação indica que os déficits devem ser financiados pela emissão de dívida pública $(\Delta B)$ ou pela emissão monetária $(\Delta H)$. Desconsiderando o papel da senhoriagem, por simplicidade e por ser desprezível nos sistemas financeiros modernos (Allsopp e Vines, 2005; Leeper e Walker, 2013), os déficits públicos implicam em acúmulo de dívida. Se $Y_{t}$ é produto no período $t$, a dívida se acumula por:

$$
B_{t} / Y_{t}-B_{t-1} / Y_{t-1}=(r-g) * B_{t-1} / Y_{t-1}+(G-T) / Y_{t}
$$

onde $r$ é a taxa de juros real $(i=r-\pi)$ e $g$ o crescimento real do produto. Fazendo $B / Y=b$ e o déficit primário, $(G-T) / Y=x$, a equação fica:

$$
\Delta b=b(r-g)+x
$$

A equação 3 indica que a evolução da dívida/PIB depende do estoque de dívida, da taxa de crescimento do produto, da taxa de juros e do déficit primário (todos em termos reais). Nessa abordagem, a dívida é sustentável quando $\Delta b$ diminua até se tornar zero ou negativo ao longo do tempo ${ }^{12}$. O argumento é que, além do risco de default e das instabilidades macroeconômicas se ele ocorrer, um aumento da dívida, avaliado como instável pelos detentores de títulos, expõe a economia a uma série de problemas: a política monetária anticíclica enfraquece, o financiamento externo fica oneroso devido a um aumento do risco soberano, as taxas de juros requeridas para o (re)financiamento da dívida aumentam, a capacidade de atrair investimento externo diminui ${ }^{13}$.

Além desses problemas, o crescimento da dívida pode levar a um aumento do nível de preços da economia, segundo a parcela do mainstream que defende a Teoria Fiscal do Nível de Preços (TFNP). Para esses autores ${ }^{14}$, o governo tem uma

(11) Alguns autores apontam essa incompletude, por exemplo, Arestis e Sawyer (2003), Allsopp e Vines (2005), Chari et al. (2008), Fontana (2009) e Arestis (2008).

(12) Não há nenhum nível pré-determinado em que a relação dívida/PIB seja considerada sustentável. Tampouco se pode achar consenso na literatura, de todas as vertentes, que aponte qual taxa de endividamento público é considerada insustentável. Veja, por exemplo, a discussão trazida por Reinhart e Rogoff (2010) tanto no meio acadêmico quanto nas páginas do "New York Times" e imprensa especializada em 2013.

(13) Ver Heller (2002), FMI (2009) e Devereux (2010).

(14) Por exemplo, Leeper (1991); Woodford (1998); Cochrane (1998) e Leeper e Walker (2013). 
restrição orçamentária intertemporal que indica que a dívida será paga em algum momento no futuro pela geração de superávits primários, segundo a equação:

$$
B_{t} / P_{t}=E_{t}[P V(\text { superávits })]
$$

onde $P$ é o nível de preços da economia e $P V$ (superávits) é o valor presente esperado dos superávits primários do governo.

Para a TFNP, se a condição de equilíbrio da equação 4 for violada temporariamente, é possível que haja um amento no nível de preços da economia. Segundo o argumento, isso ocorre quando um aumento do gasto gera um déficit que os agentes avaliam que não será financiado por aumento de tributos no futuro. A emissão de dívida para financiá-lo é percebida como um aumento na riqueza dos detentores dos títulos, que aumentarão o consumo e, após um efeito temporário nas quantidades, pressionarão os preços, até que o equilíbrio seja reestabelecido (Cochrane, 1998; Leeper; Walker, 2013).

Tanto em 3 quanto em 4 a variável de ajuste é o resultado fiscal. Em 3 argumenta-se que o governo pode afetar $x$ de maneira mais direta que $r$ ou $g$ e, em 4, como controlar a inflação é objetivo macroeconômico, o governo deve mostrar comprometimento com uma trajetória esperada de obtenção de resultados primários que garantam hoje um valor real estável da dívida e que evite um aumento no nível de preços. Assim, para manter a dívida sustentável e mostrar aos agentes que eventuais déficits não são desproporcionais à capacidade do governo se financiar, nessa abordagem, o governo deve controlar suas contas. Na prática, a sustentabilidade da dívida requer o ajuste do superávit primário, para estabilizar a relação dívida/PIB. Nesta forma de pensar, independente da origem do problema com impacto nas contas públicas, seja decorrente da necessidade de sustentar o câmbio, de garantir o nível da taxa de juros básica ou de outra natureza, é preciso ajustar o superávit primário.

O movimento teórico consolidado pelo NCM resumiu a política fiscal na análise de dois indicadores básicos: o resultado primário, capitado pela NFSP, e a relação dívida/PIB. O foco deixou de ser o valor corrente e os efeitos do déficit público na demanda agregada e se tornou o ajuste intertemporal das contas públicas, calculado a partir dos valores prospectivos dos seus determinantes. Numa teoria que considera a moeda neutra, essa é uma tentativa de acolher o mundo dos grandes estoques e fluxos de capital. No que segue, fazemos a crítica a essa visão, usando a ótica de uma economia monetária da produção.

\section{A crítica ao NCM pela ótica de uma economia monetária da produção}

$\mathrm{Na}$ abordagem aqui proposta, a política fiscal, mesmo entendida em seu sentido mais restrito, vinculada a receitas e despesas orçamentárias, deve ser compreendida em estrita relação com o conceito de economia monetária da 
produção. A dicotomia entre produção e consumo, que as principais vertentes do pensamento econômico dominante sustentam, é falsa. A segregação entre um mundo da produção e outro do consumo, que se encontram no momento das trocas, apenas serve para retirar da moeda seus atributos mais relevantes numa economia capitalista.

Mas a ideia de neutralidade da moeda, tão cara ao pensamento dominante, possui uma derivação que afeta a discussão que temos em tela de maneira absoluta. Se o mundo da produção define o produto social por uma lógica própria, derivada da composição dos fatores produtivos, ao largo, portanto, da moeda, se segue que a flutuação da quantidade desta só produzirá alteração no nível de preços. Em verdade, a criação de moeda, sob uma noção de neutralidade, não tem nenhuma funcionalidade na dinâmica da economia.

Da noção de neutralidade da moeda deriva uma forma de entendimento das responsabilidades do Estado no desempenho de suas funções como poder emissor ou regulador da emissão monetária. De um lado, via BC, uma instituição de Estado, no controle da liquidez do sistema e, de outro, na gestão do caixa do Tesouro Nacional (TN), cujo déficit significaria a expansão monetária, na forma de gastos superiores às receitas ${ }^{15}$.

Ao contrário da visão quase pueril sobre a forma de entrada da moeda nas transações econômicas, a forma defendida por Keynes (1930) parece mais realista ${ }^{16}$. A moeda é um espelho das relações sociais que são produzidas ao longo das transações econômicas. Ao contrário de apenas servir como lubrificante para as trocas, a moeda é, em primeira instância, uma forma de contratualização, na qual os agentes dão expressão às decisões de produção, consumo e investimento.

O entendimento da entrada da moeda na economia, como elemento neutro, condiciona uma compreensão do papel do déficit público na dinâmica econômica que é muito semelhante nas abordagens do NCM e da velha síntese. Entende-se que as transações recebem uma pressão adicional pela presença do Estado com gastos superiores às receitas. Assim, o aparelho econômico recebe uma pressão externa. $\mathrm{Na}$ velha síntese, especialmente nas suas versões iniciais, a pressão do déficit era benéfica por ocupar o espaço de uma tendência ao subconsumo. Na concepção do NCM, ao contrário, a pressão fiscal é entendida como "dominância fiscal" e trabalha

(15) Logicamente, o financiamento dos déficits, em sistemas financeiros complexos, não é realizado por expansão monetária, mas conta com estratégias de colocação de títulos ou financiamento bancário. No entanto, as consequências econômicas destas alternativas são semelhantes à expansão monetária, especialmente porque a tese basilar é de que a produção social está decidida em outro âmbito.

(16) Diferentemente da abordagem do NCM, o conceito relevante de moeda para a discussão da política fiscal a que este artigo se propõe é de perspectiva de Keynes (1936), que assume a importância da moeda como elemento decisivo da dinâmica da acumulação capitalista. 
para instabilizar o sistema, seja pela via do excesso de demanda, seja pela tendência à insustentabilidade do ritmo de crescimento da dívida.

Em oposição a essa abordagem, pela ótica da demanda efetiva, o Estado não apenas gera demanda agregada, mas, especialmente, atua na mobilização das ações e expectativas dos agentes, que tomam decisões sobre a produção (Keynes, 1936; Davidson, 1978; Carvalho, 2008). Logicamente, as decisões são tomadas por comparação entre o último período de produção e as expectativas de mudança para o próximo. Em toda a dinâmica econômica o Estado é elemento de grande peso e exerce forte impacto sobre as decisões dos agentes quanto à demanda efetiva. Nos dias atuais esta interação dinâmica reveste-se de novos elementos, sendo produzida e mantida num ambiente econômico muito mais complexo, notadamente pela dimensão dos ativos e da riqueza e por sua influência sobre produção e investimento.

O movimento feito pelo NCM no campo fiscal abandona os fluxos de demanda para focalizar nas posições de ativos e, de maneira indireta, buscar as repercussões sobre o nível de atividade. O mérito em perceber o fortalecimento dos determinantes financeiros e das posições de ativos, perde-se ao não avançar a análise do impacto desses determinantes sobre a dinâmica da própria dívida pública, consubstanciados em diferentes movimentos que não estão relacionados ao comportamento das receitas e despesas fiscais, mas às formas de atuação do Estado, em diferentes frentes, preocupadas com a condução da política monetária ou no seu papel de gestor financeiro. Em realidade, a abordagem do NCM apenas reiterou, no âmbito da política fiscal, o movimento mais amplo do processo de acumulação capitalista, caracterizado pela financeirização, sem discutir propriamente as diversas facetas da atuação do Estado que impactam nos indicadores fiscais.

Dentro da miríade de definições possíveis, entre as quais se reconhece a vanguarda da proposição de Braga $(1993)^{17}$, o conceito de financeirização que melhor capta a dinâmica fiscal (presente no Brasil) é o de Epstein (2005, p. 3):

...financialization means the increasing role of financial motives, financial markets, financial actors and financial institutions in the operation of the domestic and international economies.

No âmbito das economias nacionais a financeirização é caracterizada pela acumulação de riqueza ${ }^{18}$ através da concorrência acirrada nos mercados de crédito e

(17) “A dominância financeira - a financeirização - é expressão geral das formas contemporâneas de definir, gerir e realizar riqueza no capitalismo. Por dominância financeira apreende-se, inclusive conceitualmente, o fato de que todas as corporações têm em suas aplicações financeiras, de lucros retidos ou de caixa, um elemento central do processo de acumulação global de riqueza" (Braga, 1993, p. 26 - ênfase no original).

(18) A lógica financeira domina as decisões e a concorrência intercapitalista, configurando assim a financeirização como padrão de acumulação de riqueza. Esse padrão é "sistêmico porque a financeirização está constituída por componentes fundamentais da organização capitalista, entrelaçados de maneira a estabelecer uma dinâmica estrutural segundo princípios de uma lógica financeira geral” (Braga, 2000, p. 270). 
de capital, interconectados pela securitização ${ }^{19}$. No plano internacional, o conceito expressa o padrão de riqueza negociada no mercado de capitais, mundialmente integrado e tendo o dólar como seu denominador ${ }^{20}$ (Braga, 2000). No Brasil a financeirização está expressa na dominância que a dívida pública coloca sobre as outras formas acumulação de ativos financeiros e nos próprios condicionantes financeiros de sua evolução, frente aos determinantes estritamente fiscais. Na seção seguinte, por meio da análise da dinâmica fiscal brasileira, discutimos a fragilidade da abordagem e a incapacidade dos indicadores utilizados pelo NCM em captar a atuação do Estado numa economia financeirizada.

\section{Contas públicas e política fiscal no Brasil: instrumentos inadequados, teorias insuficientes}

Faz parte do senso comum e do discurso corrente dos economistas que a dívida pública é a soma dos déficits passados. Entretanto, o mundo capitalista financeirizado caracteriza-se muito mais por uma incessante criação e destruição de ativos e passivos. Em verdade, as relações entre a dívida e os déficits incorridos pelo governo não são evidentes. Muito mais fortes são os elos que a dívida tem com a gestão da liquidez e da riqueza e com o câmbio e os fluxos financeiros externos, sobretudo numa economia instável como a brasileira, em que é crucial a presença estatal para garantir segurança em diferentes frentes da regulação de ativos e passivos financeiros e cambiais.

A discussão sobre a política fiscal brasileira enfrenta dificuldades de grande magnitude. Num capitalismo financeirizado e crescentemente comandado pela lógica da valorização de estoques de riqueza, seguir formulando e executando políticas focalizadas em tributos e gastos reais jamais dará lugar a um manejo minimamente consistente das políticas macroeconômicas. Conceitos de mensuração do déficit e das dívidas públicas, formulados para o mundo dos anos 1950 e 1960, onde a predominância era dos fluxos econômicos, não são adequados para mensurar as questões fiscais num ambiente onde os grandes estoques de riqueza dominam a dinâmica da economia.

No que segue mostramos que a política fiscal responde a questões financeiras e patrimoniais de dimensão muito mais amplas que aquelas relacionadas apenas à capacidade de gerir tributos e despesas. A questão é delicada, pois a

(19) Entendida basicamente como o processo de transformação de ativos não negociáveis em negociáveis, numa coletivização das poupanças individuais e pelo processo de definir, gerir e distribuir riqueza financeira.

(20) Como é amplamente reconhecida, a financeirização como o modo de ser do capitalismo contemporâneo surge nos anos 1960 nos EUA e se intensifica no processo de liberalização financeira, de mobilidade de capitais e da supremacia do dólar no padrão monetário-financeiro internacional, desde o fim de Bretton Woods (Tavares, 1997; Braga, 2000). 
inadequação dos instrumentos de medida e monitoramento da política fiscal produz equívocos de diagnóstico e ainda mais instabilidade e descrédito ${ }^{21}$.

Nas diversas abordagens a temas específicos da política fiscal, que veremos na sequência, fica muito clara a imbricação entre as contas públicas e as diversas formas de intervenção estatal na condução das políticas econômicas. Seja por sua participação na gestão de reservas internacionais e no mercado cambial, seja por suas intervenções na disponibilização de crédito e no seu custo, as políticas geram custos fiscais que vão muito além da visão dominante sobre as contas públicas, mas se referem à participação no Estado na gestão dos fluxos financeiros e cambiais, do crédito e dos patrimônios privados.

\subsection{A capacidade das medidas de déficit em aferir os impactos reais e financeiros}

As correntes dominantes no debate econômico atual sustentam que as contas públicas podem gerar insegurança na estrutura de preços e ativos futuros, efeito que é transmitido pelos movimentos da dívida pública em sua interação com os portfólios dos agentes privados. Vale notar que a sustentabilidade da dívida, enquanto ativo financeiro e passivo do Estado, é umbilicalmente ligada à gestão corrente das contas públicas, dado que um desequilíbrio pontual pode ser compreendido como tendência de longo prazo, com impacto na dívida e em suas condições de financiamento futuras.

A forma pela qual as contas governamentais aparecem no NCM, em verdade, tem por base uma teoria de portfólios privados onde os poupadores dividem seus ativos entre títulos diversos. O desequilíbrio das contas públicas, expandindo a necessidade de financiamento para o Estado, pressiona os poupadores a alterarem suas carteiras, o que afeta as condições de risco dos papéis e taxa de juros da economia. Ao mesmo tempo, a procura por financiamento espelha a expansão do gasto público e sua pressão sobre a oferta global.

O conceito de NFSP, tradicional medida utilizada pelo FMI em suas políticas de ajuste, foi acolhido pelo NCM como forma de medir o impacto das contas públicas na economia. É o déficit nominal, base para contabilização do resultado primário, pela extração de receitas e despesas financeiras. Importante notar que não é uma diferença entre receitas e despesas de caixa, mas uma aferição da variação do estoque de obrigações do Estado, em diversas formas de endividamento.

Desde o início da mensuração do NFSP, nos anos 1980, os conceitos nominal e operacional conviveram como forma de aferição das contas públicas. Em

(21) A análise aqui realizada é dos últimos 15 anos, mas a preocupação maior é com os movimentos de política que demonstram as implicações financeiras e cambiais sobre a gestão e os resultados da política físcal. As descontinuidades de séries temporais também colocam obstáculos à apresentação de todos os dados para o período. 
verdade, a diferença entre os dois é a correção monetária e cambial do endividamento $^{22}$. No final dos anos 1990, o BC do Brasil deixou de publicar o déficit operacional, fixando-se nos resultados nominal e primário.

A decisão de abandonar o resultado operacional do setor público não é trivial, justamente porque o confronto das contas públicas é com a poupança privada, que financia seus desequilíbrios, o que vai dar forma à percepção de sustentabilidade da dívida pública. O que está em causa para o NCM é que o financiamento ao setor público não avance sobre a poupança, deslocando o setor privado.

Nesse aspecto, faz toda a diferença avaliar a política fiscal por conceito operacional ao invés do nominal ${ }^{23}$. Em sua gestão de portfólios, os agentes privados incorporam as correções do valor nominal de seu estoque de aplicações. A não ser que haja uma crise de confiança nos títulos públicos, o espaço para financiar a correção nominal desses títulos está garantido pela manutenção da mesma proporcionalidade entre dívidas de tomadores públicos e privados nos portfolios dos aplicadores $^{24}$.

Vale observar que a proposições política fiscal que indicam a necessidade de zerar o déficit nominal implicam em redução da participação dos títulos públicos no conjunto dos portfólios privados. Mas não foi por isso que se começou a monitorar o NFSP. O temor era a pressão do Estado por expansão da participação dos títulos públicos na carteira conjunta dos aplicadores.

O déficit operacional, na forma medida pelas estatísticas atuais, está longe de ser um bom sinalizador das contas públicas, mas, pelo exposto acima, é superior ao déficit nominal, na avaliação dos dois âmbitos principais das relações entre o público e o privado. De um lado, o impacto do conjunto do setor público sobre a demanda agregada e, de outro, a pressão exercida pela busca de financiamento sobre os portfólios dos poupadores e detentores de riqueza financeira.

(22) Lembrando que o déficit operacional é o déficit nominal menos as correções monetária e cambial.

(23) Blanchard (1990, p. 19), ao discutir medidas para os impactos da política fiscal na economia defende o déficit ajustado pela inflação: "The evidence reviewed above suggests that, if the choice is between adjusting or not adjusting for inflation, adjusting probably dominates. Thus, the first indicator of fiscal impact I suggest is simply the inflation adjusted deficit as a ratio to GDP" (Grifos no original). Já Blejer e Cheasty (1991, p. 1666-1667) justificam o uso do déficit operacional de maneira mais clara: "The operational deficit excludes inflation-induced interest payments on the assumption that they are similar to amortization payments in their effects on the economynamely, that they do not represent new income to recipients, and are willingly reinvested in government bonds, at existing market conditions, and therefore they do not affect the level of aggregate demand in real terms".

(24) Um exemplo simples desta questão: se um aplicador tem, no início do ano, um portfólio de R $\$ 100$ milhões, igualmente distribuído entre títulos público e privados, uma inflação de $4 \%$ ao ano fará com que ele tenha R\$ 104 milhões, ao final do mesmo ano. Para manter a proporcionalidade inicial, o aplicador, ao final do ano terá R \$ 52 milhões em títulos públicos e outros R 52 milhões em títulos privados. Ou seja, sem alterar condições de mercado, o espaço para financiar R \$ 2 milhões em títulos públicos está dado pela própria dinâmica do processo. 
Embora o BC não publique os dados, uma dedução do déficit operacional pode ser realizada a partir do NFSP, como explicitado na Tabela 1. Do NFSP tradicional (déficit nominal) foi deduzida a atualização monetária embutida no principal das dívidas, que é reportada pelo $\mathrm{BC}$ na tabela de Usos e Fontes das NFSP $^{25}$. Dentre os 15 anos entre 2002 e 2016, 6 apresentaram superávit operacional. Até 2013 os números eram bastante oscilantes e, mesmo nos momentos de déficit operacional, implicavam baixo impacto na economia ${ }^{26}$. É verdade que o triênio 2014/2016 coloca uma realidade totalmente nova, mas, como veremos à frente, as contas destes anos espelham a deterioração das condições econômicas, com impactos importantes sobre as receitas públicas e diversas ações estatais de natureza financeira e patrimonial.

Tabela 1

Déficit Nominal e Déficit Operacional - 2002 a 2016 - Em \% do PIB

\begin{tabular}{l|c|c|c|c|c|c|c|c|c|c|c|c|c|c|c}
\hline & $\mathbf{2 0 0 2}$ & $\mathbf{2 0 0 3}$ & $\mathbf{2 0 0 4}$ & $\mathbf{2 0 0 5}$ & $\mathbf{2 0 0 6}$ & $\mathbf{2 0 0 7}$ & $\mathbf{2 0 0 8}$ & $\mathbf{2 0 0 9}$ & $\mathbf{2 0 1 0}$ & $\mathbf{2 0 1 1}$ & $\mathbf{2 0 1 2}$ & $\mathbf{2 0 1 3}$ & $\mathbf{2 0 1 4}$ & $\mathbf{2 0 1 5}$ & $\mathbf{2 0 1 6}$ \\
\hline Nominal & 4,42 & 5,18 & 2,88 & 3,54 & 3,57 & 2,74 & 1,99 & 3,19 & 2,41 & 2,47 & 2,26 & 2,96 & 5,95 & 10,22 & 8,95 \\
\hline Primário & $-3,19$ & $-3,24$ & $-3,69$ & $-3,74$ & $-3,15$ & $-3,24$ & $-3,33$ & $-1,94$ & $-2,62$ & $-2,94$ & $-2,18$ & $-1,71$ & 0,56 & 1,85 & 2,48 \\
\hline Juros Internos & 6,54 & 7,36 & 5,71 & 6,64 & 6,38 & 5,95 & 5,40 & 5,14 & 5,00 & 5,43 & 4,46 & 4,66 & 5,37 & 8,33 & 6,45 \\
\hline Juros Reais & $-0,04$ & 5,32 & 1,98 & 6,14 & 4,92 & 2,61 & 1,94 & 5,45 & 0,62 & 3,60 & 1,29 & 2,50 & 3,82 & 3,52 & 3,20 \\
\hline Atualiz. Monetária & 6,58 & 2,05 & 3,73 & 0,50 & 1,46 & 3,34 & 3,46 & $-0,31$ & 4,39 & 1,84 & 3,18 & 2,17 & 1,55 & 4,81 & 3,25 \\
\hline Juros Externos & 1,07 & 1,06 & 0,86 & 0,64 & 0,34 & 0,02 & $-0,08$ & 0,00 & 0,02 & $-0,02$ & $-0,02$ & 0,00 & 0,01 & 0,04 & 0,02 \\
\hline Operacional & $-2,16$ & 3,14 & $-0,85$ & 3,04 & 2,11 & $-0,60$ & $-1,47$ & 3,50 & $-1,98$ & 0,63 & $-0,91$ & 0,79 & 4,40 & 5,41 & 5,70 \\
\hline
\end{tabular}

Fonte: Elaboração própria a partir das séries temporais do BC.

Gráfico 1

Resultado nominal e operacional - Em \% do PIB

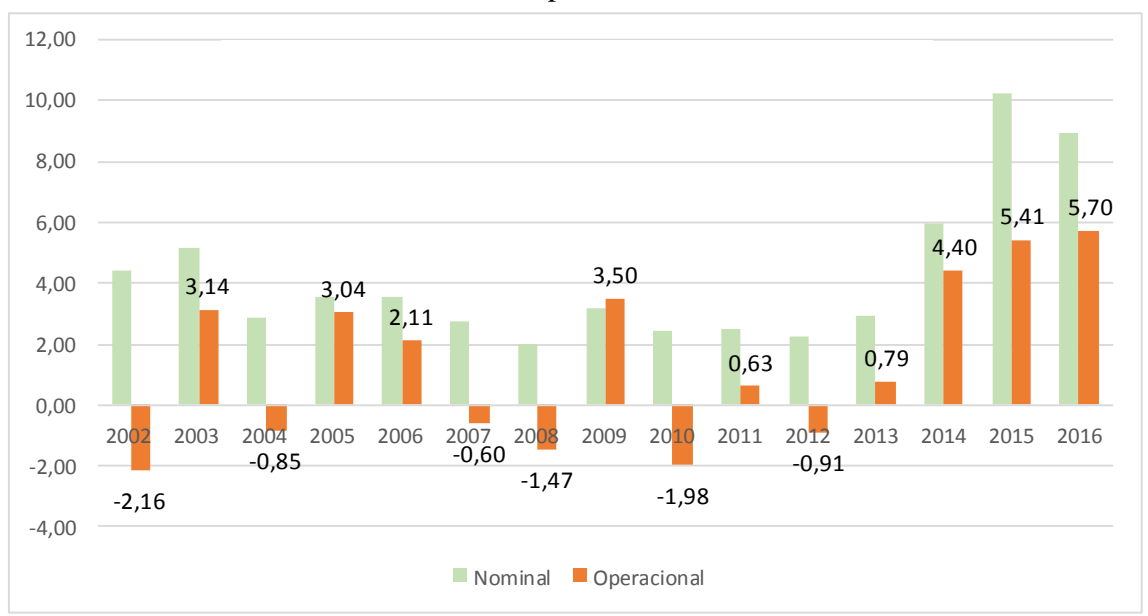

Fonte: Tabela 1.

(25) Dados compilados do BC e referem-se sempre à metodologia pós 2008, excluídos dos conceitos tanto a Eletrobrás quanto a Petrobras. Lembrando que, por se tratar de NFSP, o resultado positivo é déficit e o negativo, superávit.

(26) No entanto, há dúvidas quanto aos valores consignados como atualização monetária pelo BC. A volatilidade é bem superior à registrada nos índices de preços e o ano de 2009 causa especial interrogação, uma vez que a atualização é negativa em $0,31 \%$ do PIB. 
Da análise dos déficits nominal e operacional emergem duas observações cruciais. A primeira, de que a demanda agregada, pelo menos até o final de 2013, foi muito pouco afetada pelas contas do governo. Ao invés do governo ser elemento ativo na indução da dinâmica econômica, ele até se colocou contra ela, ao retirar mais tributos do que injetar recursos na forma de despesas. O Gráfico 1 mostra que isto é verdade para metade dos 12 anos que precedem a crise (de 2002 a 2013). Notese que, no ano de maior déficit operacional, o determinante não foi nem a política fiscal, mas o processo recessivo importado da crise mundial.

A segunda observação é relativa ao campo financeiro. Partindo do suposto, altamente realista para uma economia como a brasileira, de que a atualização monetária é acomodada nas carteiras dos aplicadores, a Tabela 1 mostra que a pressão exercida foi muito baixa na maioria dos anos, sendo negativa em alguns deles. Em 2003 e 2009, a macroeconomia teve o papel essencial e aí os problemas são de outra ordem, que discutiremos mais à frente. O triênio 2014/2016 mostrou o óbvio: a um Estado desarticulado, que se transformou em polo dinâmico da retração, só poderia corresponder uma crise de financiamento, com todos os problemas frente ao mercado decorrentes da deterioração da confiança na capacidade do Estado em gerir suas contas.

Em que pese não ser o objetivo deste artigo a aferição do impacto fiscal do período, é possível sustentar que, olhando por um conceito mais adequado - o operacional, embora não oficial, não há como imputar às contas fiscais um papel de pressão sobre a economia, seja na demanda global, seja na posição de portfólios. Em verdade, mesmo no período de 2010 a 2013 seria mais correto dizer que o Estado exerceu pressão quase nula. Já no período de crise de 2014 a 2016, frente a uma economia estagnada, as contas públicas acabam por exercer pressão sobre demanda e financiamento ${ }^{27}$.

\subsection{Reservas internacionais e custos fiscais}

A política cambial é marcada pela gestão dos fluxos e dos riscos comerciais e financeiros com exterior, o que envolve escolhas entre várias alternativas. No atual regime cambial, marcado pela liberdade de capitais, a preponderância dos fluxos financeiros sobre os comerciais agudizou os riscos na administração do BP. Em verdade, as ações da política econômica, desde meados dos anos 1990, buscaram facilitar a entrada de recursos. O mercado internacional, dada a ampliação de liquidez e a busca de remunerações mais altas que as oferecidas nos mercados tradicionais, inundou o Brasil de investimentos, sob as mais diversas formas e

(27) Os autores não consideram as medidas de déficit realizadas por meio do NFSP as mais corretas. A necessidade de construção de conceitos e formas de aferição da política fiscal é premente e apresenta-se como um pano de fundo do presente artigo. 
modalidades. Logicamente, a taxa de juros oferecida nas dívidas públicas, permanentemente elevadas em termos reais, construiu processos de forte atração de capitais.

O Brasil optou, como vários outros países, por não colocar restrições à entrada ou à saída de capitais ${ }^{28}$. O acúmulo de Reservas Internacionais (RI) pelo BC foi, deste modo, a principal política de mitigação de riscos adotada pela política econômica brasileira: uma política de Estado que envolve custos para o Estado, refletidos nas autoridades monetárias, nas contas fiscais e no endividamento público.

O custo da política de manutenção de amplas reservas cambiais é, grosso modo, a diferença entre a taxa de aplicação das RI, pelo BC, nos mercados globais, e o custo em Reais de remuneração dos investidores internacionais. Em outras condições macroeconômicas, seria legítimo pensar que parcela dos investimentos externos no Brasil pudesse estar aplicada em operações com o setor privado, operando no mercado interno e, portanto, a remuneração do investimento seria privada e não pública. Por isso, os cálculos que se seguem buscam isolar o componente de custos que é arcado pelo setor público.

Avaliando o ano de 2015, a Tabela 2 apresenta os cálculos do custo fiscal da manutenção das RI, segundo seus estoques no final de cada mês. A linha "remuneração das $R P^{\prime}$ ' indica os valores recebidos, a uma taxa anual de aplicação de $0,6 \%$ ao $a^{29}$. A Selic mensalizada foi aplicada aos estoques das RI, com o que se apurou o custo da colocação de títulos públicos que enxugam a liquidez gerada pelas RI no mercado financeiro doméstico. Os valores indicam que o custo líquido da manutenção de RI foi de $\mathrm{R} \$ 69,3$ bilhões naquele ano, o que significa $1,16 \%$ do $\mathrm{PIB}^{30}$.

Considerando que o país dispõe do triplo de RI do que os fluxos comerciais legitimariam, seu custo fiscal seria de $0,77 \%$ ao ano. Mas, vale notar, este é o piso da estimativa. Um aspecto que poderia ser levado em consideração é que os investidores internacionais que, na conversão de dólares em Reais aumentam as RI, não são aplicadores em papeis vinculados à Selic, mas em papeis prefixados (NTNF e LTN). Os rendimentos destes superaram os dos atrelados à Selic em 3 a $4 \%$ reais ao ano.

(28) Num breve período foi estabelecida uma penalidade para a entrada de capitais, com a incidência de IOF, o que limitava a lucratividade do investimento externo no Brasil. Ver: Prates et al. (2014).

(29) Este exercício não pretende mostrar valores efetivos, mas apenas identificar a magnitude do problema. Vale observar que, segundo o Balanço do BC de 2015, a remuneração foi expressivamente menor que a utilizada neste exemplo.

(30) As notas à imprensa sobre o mercado aberto, publicadas mensalmente pelo BC, evidenciam o direcionamento das aplicações dos não-residentes em títulos prefixados do TN. 
Tabela 2

Custo fiscal da manutenção de Reservas Internacionais - 2015-Em R\$ milhões

\begin{tabular}{|c|c|c|c|c|c|c|c|c|c|c|c|c|c|}
\hline & jan & fev & mar & $a b r$ & mai & jun & jul & ago & set & out & nov & dez & Total \\
\hline Reservas Internac. & 979.510 & 1.058 .967 & 1.177 .007 & 1.103 .873 & 1.168 .231 & 1.141 .536 & 1.244 .111 & 1.335 .967 & 1.455 .608 & 1.415 .308 & 1.404 .906 & 1.423 .637 & \\
\hline Remuneração & 5.893 & 6.371 & 7.081 & 6.641 & 7.029 & 6.868 & 7.485 & 8.038 & 8.758 & 8.515 & 8.453 & 8.565 & 89.698 \\
\hline Selic Mensalizada & $0,96 \%$ & $0,89 \%$ & $1,02 \%$ & $0,99 \%$ & $1,06 \%$ & $1,06 \%$ & $1,10 \%$ & $1,14 \%$ & $1,10 \%$ & $1,14 \%$ & $1,10 \%$ & $1,14 \%$ & \\
\hline Custo das RI & 9.407 & 9.429 & 12.000 & 10.955 & 12.411 & 12.111 & 13.718 & 15.202 & 16.026 & 16.105 & 15.468 & 16.200 & 159.031 \\
\hline Saldo negativo & 3.514 & 3.058 & 4.918 & 4.313 & 5.383 & 5.242 & 6.232 & 7.164 & 7.269 & 7.590 & 7.015 & 7.634 & 69.332 \\
\hline Custo em $\%$ do PIB & & & & & & & & & & & & & 1,16 \\
\hline
\end{tabular}

Fonte: Elaboração própria a partir da Nota para a Imprensa sobre Setor Externo e séries temporais, ambas do BC.

Algumas questões devem ser pontuadas com respeito à estimativa acima. Em primeiro lugar, o elevado custo de manutenção das RI é fruto de duas distorções: a) o abismo entre a remuneração das aplicações do BC no mercado internacional e a taxa de juros paga nos títulos brasileiros vendidos no mercado interno; e b) a desproporção dos fluxos financeiros que provocam riscos à gestão da paridade cambial e induzem autoridades econômicas a buscarem grandes volumes de RI como garantia contra movimentos especulativos. Mas é importante ter em mente que este desenho de relações com setor externo é, em última instância, uma decisão da política macroeconômica que implica custos fiscais.

A segunda questão é relativa à forma como o custo fiscal das RI se transforma em gasto do TN. Na verdade, não se trata de um gasto direto e nem primário. A Lei n. 11.803/2008 ${ }^{31}$, que dá suporte à equalização cambial, estabelece que os custos com operações cambiais do BC são, semestralmente, compensados pelo TN mediante a emissão direta de títulos do TN para a carteira do BC. Não se trata, portanto, nem de gasto efetivo e nem mesmo afeta o resultado primário. Mas o custo cambial aumenta o endividamento público e gera encargos para o TN com a remuneração dos títulos entregues ao BC. Vale frisar que, mesmo na ausência da Lei, o custo fiscal das RI exerceria pressão sobre Resultado de Balanço do BC e necessidade de compensação pelo TN.

\subsection{Intervenções do Estado nos mercados financeiros}

A intervenção nos mercados financeiros é outra fonte frequente de enormes custos para o Estado brasileiro. Dois casos são particularmente emblemáticos: os swaps cambiais e a interação entre o endividamento externo e o mercado de capitais. No caso dos swaps, o montante de operações realizado pelo BC cresceu de 2013 a dezembro de 2015 , quando registrou seu ponto mais elevado ( $\mathrm{R} \$ 426,8$ bilhões) para depois reverter a $\mathrm{R} \$ 85,5$ bilhões, em dezembro de 2016. O custo dos swaps chegou, no acumulado de 2015, a R 102 bilhões pelo conceito de competência ${ }^{32}$.

Mercados cada vez mais líquidos, onde posições são formadas e desmontadas em segundos, requerem instrumentos poderosos das políticas

(31) Para uma apreciação mais detida, ver Mendes (2016).

(32) Nota para a Imprensa de Política Fiscal do BC, vários números. 
econômicas para não transformar a especulação em colapso do sistema financeiro e do aparelho produtivo. O uso de instrumentos como os swaps é uma alternativa importante para a política cambial e pode envolver custo muito menor para a autoridade monetária e o sistema econômico do que a instabilidade produzida pelo processo especulativo. A operação de swaps vinculada ao câmbio, realizada pelo BC, consistiu em firmar contratos onde o BC garantia pagar a correção do câmbio se esta fosse maior que a evolução dos Certificados de Depósito Interbancário (CDI - que é praticamente a evolução da Selic). Se o CDI tivesse evolução maior que o câmbio, o ente privado pagaria a diferença ao $\mathrm{BC}$.

Embora o instrumento seja útil em momentos de aguda especulação, não resta dúvida de que, no caso brasileiro, foi usado para possibilitar um hedge patrimonial para empresas endividadas em dólar. $\mathrm{O}$ discurso oficial ${ }^{33}$ sempre afirmou que o uso dos swaps visava à sustentação da paridade cambial, sem alteração de patamar. A verdade, no entanto, era que a mudança estrutural do BP já se tornara evidente, em decorrência do fim do boom de preços de commodities.

O swap cambial foi uma política de gestão de ativos privados objetivando suavizar a mudança estrutural das relações externas. Foi usado para controlar o risco dos agentes expostos à variação do câmbio. $\mathrm{O}$ hedge oferecido pelo $\mathrm{BC}$ contra a mudança de valor, em Reais, das dívidas externas "salvou" diversos agentes endividados em moeda estrangeira.

Mas não foram apenas os agentes endividados em dólar que se aproveitaram do hedge cambial oferecido pelo BC. Em seu Relatório de Estabilidade Financeira, o BC aponta que, em jun./2015, a dívida em moeda estrangeira de empresas não exportadoras com hedge local era de 4,0\% do PIB (Gráfico 2). Isto indica que até R\$ 230 bilhões, cerca de $67 \%$ do volume de swaps cambiais àquela altura, poderiam fazer o hedge de empresas endividadas em moeda estrangeira. A diferença esse valor e o total de swaps cambiais negociados pelo BC é de mais de R 100 bilhões.

Não há informações oficiais sobre os tomadores destes swaps cambiais junto ao BC. No entanto, uma avaliação de contornos mais gerais, pode ser realizada a partir das posições de mercado. Exceto pelos bancos comerciais brasileiros que possuem a condição de ficarem vendidos em moeda estrangeira ${ }^{34}$, os grandes players do mercado não têm razões para construir posições em câmbio, ou seja, não têm por que usar mecanismos de hedge cambial.

(33) Ver, por exemplo, Mantega (2014).

(34) Desde os movimentos especulativos de 2007 a 2010, quando os bancos constituíram grandes posições em moeda estrangeira, há uma regulação, datada de 2011, que os impede de ultrapassar limites bastante estreitos. 


\section{Gráfico 2}

Dívida das empresas não financeiras por moeda - \% PIB

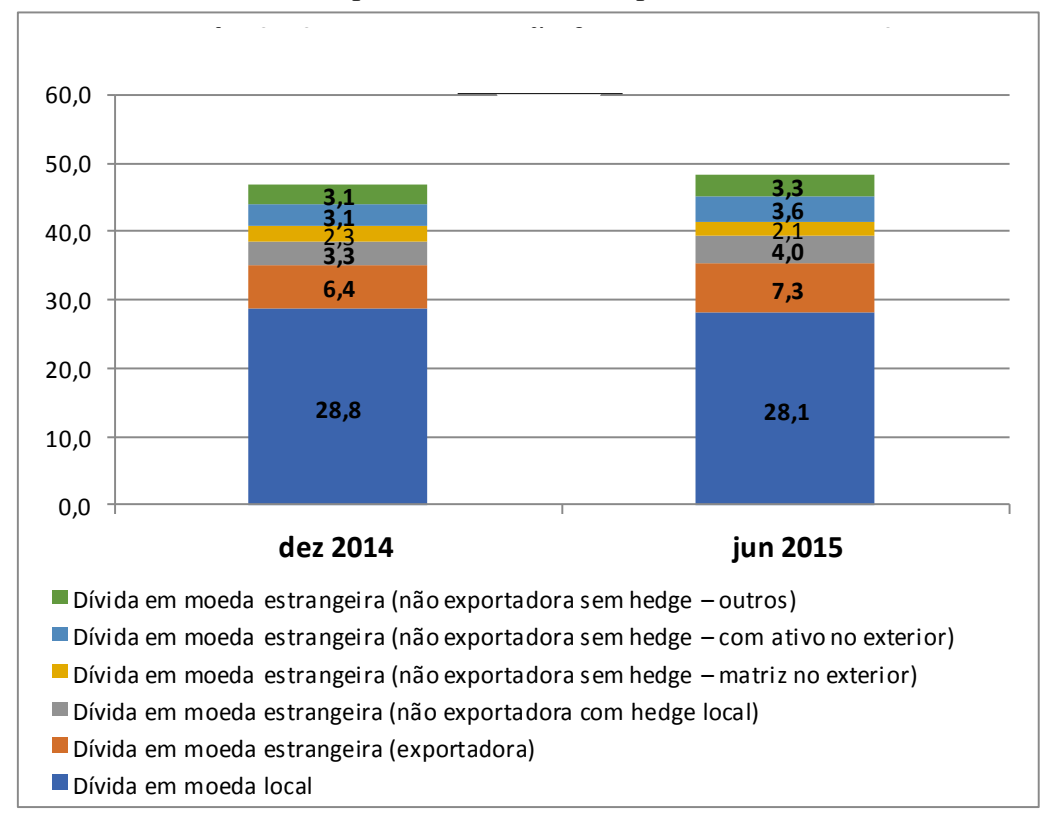

Fonte: Banco Central. Relatório de Estabilidade Financeira, out./2015.

A ausência de outros agentes demandantes de hedge para seus passivos dolarizados nos leva para outra hipótese: detentores de ativos em Reais que precisam manter valores patrimoniais em moeda estrangeira, os investidores internacionais. De fato, há uma confluência do excesso de swaps cambiais com a posição de nãoresidentes em títulos públicos. De jun./2013 a ago./2015, os investidores estrangeiros ampliaram sua posição em títulos do TN de R $\$ 258$ bilhões para $\mathrm{R} \$ 463$ bilhões, uma expansão real de cerca de 54\%. A alternativa de fazer hedge destas posições com swaps cambiais foi determinante para a forte expansão da posição dos nãoresidentes na dívida pública, que chegou a inéditos $18 \%$, ao final de $2015^{35}$.

Como nosso objetivo principal é mostrar os custos fiscais derivados das articulações institucionais que a política econômica constitui na sustentação de mercados, é relevante mostrar uma ponte entre a dívida pública e o mercado acionário. Neste caso, não se trata de algo emergencial, mas de uma articulação mais perene. A Bolsa de Valores brasileira conta, entre seus aplicadores, com uma importância desmedida dos investidores estrangeiros. Ao final de 2015, eles representavam $52,8 \%$ de todo o capital investido ${ }^{36}$. Ou seja, mesmo com toda a incerteza em torno da economia, a entrada de capitais externos na Bovespa foi de R \$ 20,3 bilhões, segunda melhor marca anual de toda história.

(35) Para uma discussão mais aprofundada ver Salto et al. (2016).

(36) FSP (2016). 
É importante atentar para o fato de que a presença de investidores internacionais na Bolsa brasileira talvez não fosse viável sem a possibilidade, concedida pela institucionalidade brasileira, de alternância de posições entre títulos públicos e aplicações em ações. De fato, a inexistência da possibilidade de aplicação em título público exigiria que, ao desmontar posições em bolsa, o investidor estrangeiro buscasse aplicar num título privado, que não existe, por falta de demandantes de crédito com condições de risco compatíveis com as expectativas dos aplicadores estrangeiros. Por outro lado, o investidor estrangeiro teria grande dificuldade em entrar ou sair do país sem uma boa forma de arbitrar a reconversão dos Reais em moeda estrangeira, especialmente numa economia volátil como a brasileira. Sair em más condições significa perda de capital na moeda de origem.

Durante o movimento mais forte de entrada de capitais externos, tanto para Bolsa como para aplicações em renda fixa (na prática, títulos públicos), a dívida pública cresceu, sem que houvesse movimento expressivo de demanda de financiamento de déficits públicos ${ }^{37}$. É evidente que a política econômica montou uma estratégia para que os investidores estrangeiros estivessem na Bolsa brasileira, mas o custo a ser arcado pelo Estado com a montagem desta estrutura é ampliar em muito os gastos com juros da dívida pública, justamente pagos aos investidores internacionais posicionados em renda fixa, o que girou em torno de 14 e $19 \%$ da dívida emitida pelo TN, nos últimos anos. $\mathrm{O}$ grande aumento da dívida pública junto a não-residentes não foi decorrente de déficits públicos, mas sua principal função acabou sendo a de dar melhores condições de arbitragem aos investidores internacionais no mercado de capitais. ${ }^{38}$

Combinando essa avaliação e a hipótese sobre os swaps cambiais lançados para além das empresas endividadas em dólares é forçoso notar que as intervenções do Estado em mercados, como o identificado, produzem responsabilidades para com as estruturas de capital e os impasses colocados pela volatilidade da moeda brasileira frente às moedas fortes. Para atrair capitais, o Estado paga um seguro na forma de rentabilidade. Para impedir a fuga de capitais, nas flutuações mais fortes do câmbio, mecanismos de transferência de capital, como os swaps, são acionados.

Em todos os casos, as políticas macroeconômicas geram custos não fiscais ao Estado brasileiro que são entendidos como custos da política fiscal e cristalizamse como dívida pública.

\subsection{O financiamento do investimento e os custos fiscais}

A estruturação do financiamento ao investimento sempre foi uma grande questão para a economia brasileira, cujo equacionamento só poderia ter no Estado

(37) No BP este influxo de capitais para aplicação em renda fixa, na verdade títulos públicos, se expressava como aumento das reservas internacionais.

(38) A Secretaria do TN emitiu os títulos comprados pelos não-residentes e deu liquidez aos mesmos, quando necessário. 
seu agente principal. A ausência de instituições privadas com capacidade para expandir o crédito e bancar o risco das aplicações fez com que o Estado, via BNDES $^{39}$, tivesse que articular a solução ${ }^{40}$.

A Dívida Líquida do Setor Público (DLSP) mostra que o TN acumulou ativos contra o BNDES de $8,4 \%$ do PIB, em nov./2016. Este valor se reduziu a $6,8 \%$ do PIB, em dezembro do mesmo ano, em razão da devolução de R $\$ 100$ bilhões que o banco promoveu. Atente-se para o fato de que as operações entre o TN e o BNDES não significam expansão da DLSP, dado que a dívida emitida tem como contrapartida um ativo do TN. No entanto, por serem expansão do volume de títulos em mercado, as operações entre o TN e o BNDES resultaram em elevação da dívida bruta governamental.

A expansão do endividamento público teve como objetivo dotar o BNDES de maiores disponibilidades para financiamento aos agentes privados. Mas este processo teve objetivos distintos a cada momento de sua realização. Numa primeira etapa, a motivação foi a reorganização da estrutura financeira das empresas frente à crise internacional. A primeira fase dos aportes ao BNDES foi, primordialmente, o suporte à administração de ativos e passivos privados, o que, logicamente, teve grande impacto na mitigação dos danos à produção e à renda corrente.

A recuperação da economia, em 2010, abriu caminho para que os aportes do TN ao BNDES tivessem características mais ligadas à expansão econômica e ao financiamento do investimento do que o perfil de aplicações ligado ao combate à crise dos anos anteriores. Neste ponto há uma inflexão importante na política econômica, dado que não se trata apenas de colocar recursos à disposição dos investidores, mas possibilitar fontes de financiamento a uma taxa de juros expressivamente menor do que a taxa geral vigente.

Uma economia onde prevalece alta taxa de juro real por longo prazo impede que o financiamento do investimento seja feito com endividamento interno. Do mesmo modo, uma economia onde a descontinuidade cambial é a norma, não há como realizar investimentos que produzam fluxo de caixa em Reais, com endividamento em moeda estrangeira. A economia brasileira apresenta as duas restrições. Nem o investimento do setor privado em estrutura produtiva, nem a nova forma de enfrentar as questões da infraestrutura, as Parcerias Público-Privadas (PPP) e as concessões, poderiam ser realizados nos contornos que a economia brasileira vinha apresentando.

(39) Uma instituição dotada de recursos derivados de mobilização compulsória.

(40) Em diversas oportunidades, o financiamento em moeda estrangeira, junto ao mercado internacional, foi alternativo à ausência de fontes de crédito de longo prazo, mas o Estado acabou assumindo os custos derivados das mudanças cambiais. 
A política econômica montou um mecanismo que, ao mesmo tempo, criava crédito e reduzia o seu custo. As emissões de títulos pelo TN e os aportes de recursos neles lastreados, ao BNDES, faziam a função que Keynes (1937) identificaria como "motivo finance". Já a divergência entre a Taxa de Juros de Longo Prazo (TJLP) e a Selic, bancada com recursos do TN, constituía-se em subsídio de crédito que viabilizava investimentos produtivos mesmo num quadro de elevadas taxas de juros reais $^{41}$. Já no campo das concessões e das PPP, o diferencial de taxas viabilizou projetos que jamais seriam executados, dado que o subsídio de crédito produzia uma taxa interna de retorno (TIR) melhor que a formalmente estabelecida ${ }^{42}$.

As operações realizadas pelo TN para ampliar a oferta de crédito pelo BNDES envolveram uma arquitetura bastante específica. O TN realizou emissões diretas de títulos públicos repassados ao BNDES. Para que recursos monetários fossem gerados, o título teria que ser vendido em mercado. Mas o caminho foi outro, os resultados do $\mathrm{BC}$, transferido em forma dinheiro à Conta Única do TN podem ser usados para resgate de dívidas. Deste modo, recursos da Conta Única resgataram títulos do TN que estavam em mãos do BNDES ${ }^{43}$.

Os críticos certamente apontariam criação de moeda, escudados no fato de que a geração dos valores desproporcionais que a Conta Única do TN acumulou não foi derivada dos superávits de receitas contra despesas. De fato, um sistema de operacionalidade bastante discutível, baseado na Lei 11.803 , ampliou de maneira inconsistente o montante de recursos da Conta Única ${ }^{44}$.

O ponto é controverso e ainda pouco estudado, mas não há como deixar de apontar que o BC agiu como um criador de crédito operado pelo BNDES. Numa abordagem pós-keynesiana, a legitimidade ou não do processo reside na forma como o dinheiro entrou na economia: a criação de crédito que é apropriada pelos mutuários e coloca em marcha decisões de compra de bens e geração de postos de trabalho é radicalmente diferente daquela onde a moeda permanece nos circuitos financeiros, apenas se auto reproduzindo. Mas a questão, num mundo do capitalismo financeirizado é ainda mais complexa, posto que é necessário analisar a forma como

(41) Os setores industriais em processo de investimento e seus fornecedores foram grandes beneficiários do Programa de Sustentação do Investimento (PSI).

(42) A esta TIR aumentada pelo financiamento com juro subsidiado o mercado deu o nome de TIR alavancada.

(43) Os elementos deste parágrafo foram objeto de exposição oral de Antonio Carlos Dávila Carvalho Jr., consultor da Câmara Federal e ex-Auditor do Tribunal de Contas da União. A apresentação aconteceu na II Jornada de Debates sobre a Dívida Pública, realizada pelo Ministério Público Federal, em Brasília, 23 e 24 de novembro de 2016. Ver o vídeo do encontro em: http://www.tvmpf.mpf.mp.br/videos/1900.

(44) A previsão da Lei 11.803 é de que sejam aferidos semestralmente todos os ganhos e perdas cambiais do BC. Os ganhos são revertidos em depósitos em dinheiro na Conta Única. As perdas são compensadas pelo TN com emissão direta de títulos à carteira do BC. A volatilidade excessiva do câmbio acaba por produzir movimentos financeiros de grande magnitude, nos dois sentidos: BC deposita grandes somas na Conta única e Tesouro emite grande quantidade de títulos ao BC. Essa é a principal explicação para a Conta Única do TN no BC ter chegado a $16 \%$ do PIB. Ver Mendes (2016). 
os recursos alteraram as posições de carteira dos agentes e como estas modificações impactaram a economia real.

\subsection{O peso do crédito e dos subsídios na execução do Tesouro Nacional}

Se a questão acima é de fronteira no pensamento econômico, outra questão não pode levantar discussões: o subsídio de crédito é um custo para a política fiscal. Não foram poucas as inserções da política de gastos do TN no crédito e nas composições de capital. Os números dos programas de Fortalecimento da Agricultura Familiar (Pronaf), de Sustentação do Investimento (PSI), Especial de Saneamento de Ativos (PESA), de Garantia da Atividade Agropecuária (Proagro), de Cooperação Nipo-Brasileira para o Desenvolvimento dos Cerrados (Prodecer), além do microcrédito e das equalizações do custeio e do investimento do agronegócio e da equalização do Programa de Financiamento às Exportações (PROEX), não deixam dúvidas ${ }^{45}$.

Entre as despesas obrigatórias, notabiliza-se a expansão dos subsídios, subvenções e programas como o Proagro. Embora as famosas "pedaladas fiscais" prejudiquem a comparação, por agregar despesas de cerca de 30 meses no ano de 2015, é fácil notar que o patamar se elevou pela observação dos dados de 2016, onde não há contaminação por despesas prévias a este ano. A expansão da despesa do TN, exceto benefícios previdenciários, entre 2013 e o triênio 2014/2016 foi de 1,07\% do PIB (Gráfico 3), sendo que apenas a expansão de subsídios e subvenções representou $31,2 \%$ desta elevação.

\section{Gráfico 3}

Despesas do TN com itens obrigatórios do OCC - 2012 a 2016 - Em \% do PIB

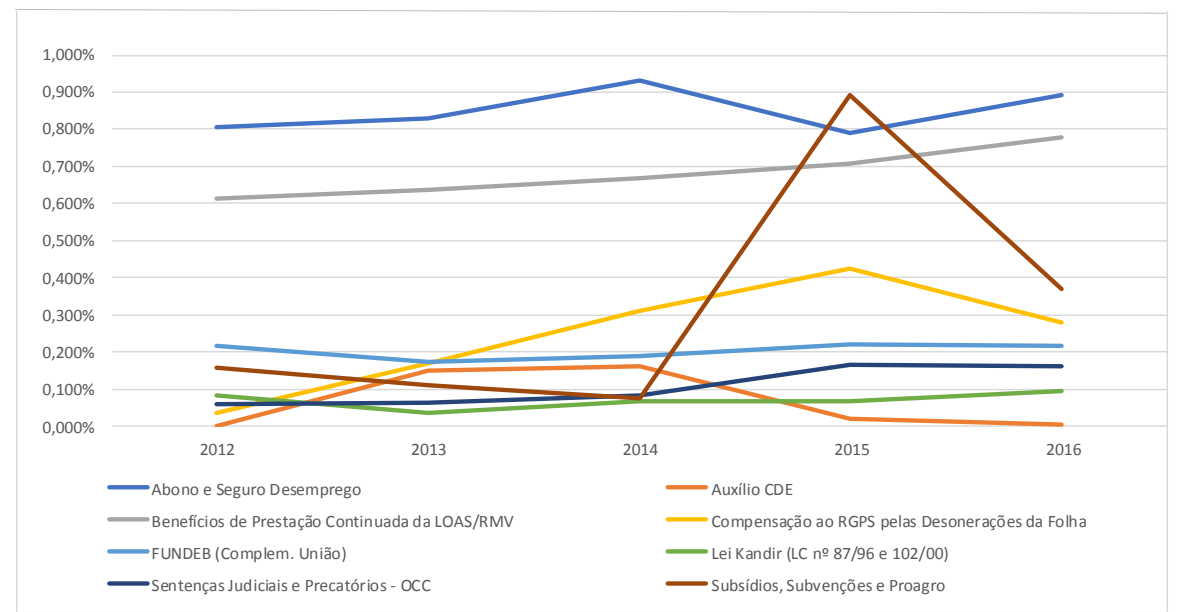

Fonte: Resultado do Tesouro Nacional. Vários números.

(45) É uma realidade histórica do Estado brasileiro uma presença muito forte na oferta de crédito, via orçamento, o que já significou recursos muito mais volumosos nos anos 1970 e 1980. 
Os dados acima não procuram discutir as pedaladas ou a pertinência da expansão do gasto. O intuito é apontar que a execução do orçamento federal é apenas um aspecto das políticas de Estado. Estas políticas englobam movimentos de política econômica que não se limitam às receitas tributárias e às despesas com pessoal e custeio. Ao contrário, as contas públicas, no mundo financeirizado, abrangem um enorme leque de ações do Estado, onde convivem desde a merenda escolar e até a intervenção nos mercados de derivativos, passando pelos subsídios creditícios. E, dada a dimensão crescente dos estoques de ativos e do risco a eles associado, a política fiscal se torna peça ainda mais decisiva no xadrez do capitalismo contemporâneo.

\subsection{Estado e dívida: um gestor financeiro travestido de gestor fiscal}

O mundo teórico do NCM tem uma concepção bastante específica para a dívida e o déficit público. De fato, a identificação de um padrão de sustentabilidade intertemporal para a evolução da dívida, numa composição entre a taxa de juros e a taxa de crescimento do produto, exige que o lado fiscal esteja equilibrado ${ }^{46}$. Há uma precedência do lado financeiro sobre o lado real nesta concepção de regime de contas públicas, do que emerge o controle da dívida como pilar da política econômica.

O conceito de NFSP já estava pronto e, há tempos, em utilização ${ }^{47}$, sendo rapidamente adotado para aferir o superávit primário realizado. A definição do conceito de dívida pública foi, a partir daí, quase automática. A DLSP ${ }^{48}$ tinha objetivo inicial de trazer ativos e passivos do Estado para os cálculos do endividamento, mas não logrou alcançar seus objetivos, limitando-se a incorporar os créditos do setor público ao setor agrícola ${ }^{49}$. Entretanto foi rapidamente eleita para medir a dívida pública e ser utilizada como balizador para a quantificação do superávit primário necessário.

A DLSP é um conceito de abrangência semelhante ao NFSP, incluindo dívidas em moeda estrangeira (bônus e bancária), dívidas bancárias internas, reestruturações, renegociações, títulos da dívida mobiliária (interna e externa), aplicações diversas de instituições financeiras no BC, posições em mercado aberto e atrasos junto a fornecedores. No lado do ativo, encontram-se os créditos fornecidos ao setor privado e público financeiro e os haveres junto a uma ampla gama de relações entre o setor público e a economia ${ }^{50}$.

(46) Como nas equações 3 e 4.

(47) Em 1981, quando do início das tratativas com o FMI sobre as cartas de intenções que davam suporte aos acordos de ajuste de BP.

(48) Peça de análise da qual o NFSP foi um espelho desde sua criação, em 1986.

(49) O objetivo do conceito de DLSP era o de compreender de forma abrangente os ativos e passivos do Estado, inclusive ações de empresas e patrimônios. As dificuldades conceituais acabaram por limitar o conceito às dívidas e créditos concedidos.

(50) Para uma discussão dos elementos do conceito, ver Jaloretto (2009). 
A evolução da DLSP mostrou uma violenta e longa redução, seguida de uma expressiva expansão no último ano. Ao final de 2002, como mostra a Tabela 3, a DLSP situava-se em $59,9 \%$ do PIB $^{51}$. A queda foi contínua até chegar a $30,5 \%$ do PIB, em 2013. Em 2014, com a deterioração das condições macroeconômicas e da situação fiscal, o estoque de dívida teve uma trajetória expansiva que chegou a 46,0\% do PIB, em 2016. Ainda assim, a DLSP caiu 13,9p.p. entre os extremos da série.

O governo federal, como mostra o Gráfico 4, reduziu sua dívida de 38,1\% em 2002 a 20,5\% do PIB em 2013. No entanto, a trajetória foi revertida, chegando a $35,7 \%$ do PIB ao final da série. Os governos regionais apresentaram uma redução, muito mais consistente, tendo a dívida caído de 17,3\%, em 2002, para 10,9\% do PIB em 2016, depois do vale registrado de 9,1\% do PIB em 2013.

Tabela 3

\begin{tabular}{l|r|r|r|r|r|r|r|r|r|r|r|r|r|r|r}
\hline \multicolumn{10}{c|}{ Dívida Líquida do Setor Público-2002 a 2016 Em \% do PIB (posic̃a em dezembro) } \\
\hline & $\mathbf{2 0 0 2}$ & $\mathbf{2 0 0 3}$ & $\mathbf{2 0 0 4}$ & $\mathbf{2 0 0 5}$ & $\mathbf{2 0 0 6}$ & $\mathbf{2 0 0 7}$ & $\mathbf{2 0 0 8}$ & $\mathbf{2 0 0 9}$ & $\mathbf{2 0 1 0}$ & $\mathbf{2 0 1 1}$ & $\mathbf{2 0 1 2}$ & $\mathbf{2 0 1 3}$ & $\mathbf{2 0 1 4}$ & $\mathbf{2 0 1 5}$ & $\mathbf{2 0 1 6}$ \\
\hline Dívida líquida total & $\mathbf{5 9 , 9}$ & $\mathbf{5 4 , 3}$ & $\mathbf{5 0 , 2}$ & $\mathbf{4 7 , 9}$ & $\mathbf{4 6 , 5}$ & $\mathbf{4 4 , 5}$ & $\mathbf{3 7 , 6}$ & $\mathbf{4 0 , 9}$ & $\mathbf{3 8 , 0}$ & $\mathbf{3 4 , 5}$ & $\mathbf{3 2 , 2}$ & $\mathbf{3 0 , 5}$ & $\mathbf{3 2 , 6}$ & $\mathbf{3 5 , 6}$ & $\mathbf{4 6 , 0}$ \\
\hline Governo federal & 38,1 & 34,0 & 31,2 & 30,4 & 30,2 & 29,7 & 24,4 & 29,2 & 26,9 & 24,3 & 22,1 & 20,5 & 22,0 & 25,0 & 35,7 \\
\hline Banco Central & $-0,4$ & $-0,3$ & $-0,4$ & 0,2 & 0,4 & 0,3 & $-1,0$ & $-1,2$ & $-1,1$ & $-1,2$ & $-1,2$ & $-1,2$ & $-1,2$ & $-3,1$ & $-2,5$ \\
\hline Governos estaduais & 17,3 & 16,2 & 15,6 & 14,1 & 13,2 & 11,9 & 11,6 & 10,5 & 10,0 & 9,2 & 9,2 & 9,1 & 9,5 & 11,0 & 10,9 \\
\hline Governos municipais & 2,4 & 2,3 & 2,3 & 2,0 & 2,0 & 1,8 & 1,8 & 1,7 & 1,6 & 1,6 & 1,6 & 1,6 & 1,6 & 1,9 & 1,0 \\
\hline Empresas estatais & 2,6 & 2,1 & 1,5 & 1,2 & 0,8 & 0,8 & 0,8 & 0,7 & 0,6 & 0,6 & 0,6 & 0,6 & 0,7 & 0,9 & 0,9 \\
\hline Federais & $-0,2$ & $-0,1$ & $-0,3$ & $-0,4$ & $-0,4$ & $-0,4$ & $-0,3$ & $-0,2$ & $-0,2$ & $-0,2$ & $-0,1$ & $-0,1$ & $-0,1$ & 0,0 & 0,0 \\
\hline Estaduais & 2,6 & 2,0 & 1,7 & 1,4 & 1,1 & 1,0 & 1,0 & 0,8 & 0,7 & 0,7 & 0,7 & 0,6 & 0,7 & 0,9 & 0,9 \\
\hline Municipais & 0,2 & 0,2 & 0,2 & 0,2 & 0,1 & 0,1 & 0,1 & 0,1 & 0,1 & 0,1 & 0,1 & 0,1 & 0,0 & 0,0 & 0,0 \\
\hline
\end{tabular}

Fonte: Elaboração própria a partir de dados do Banco de Dados BC.

Gráfico 4

Evolução dos componentes da DLSP - 2002 a 2016 - Em \% do PIB

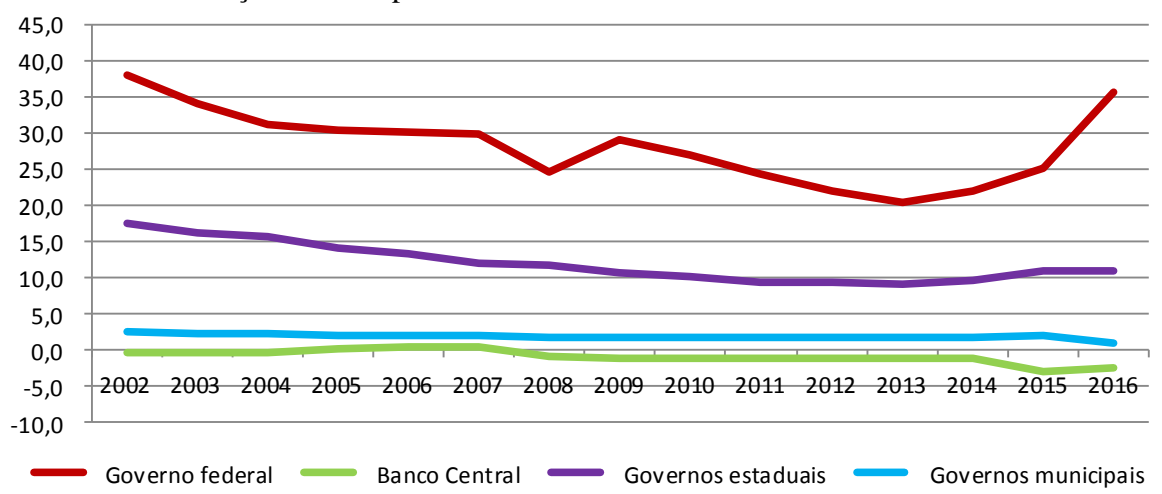

Fonte: Elaboração a partir das séries temporais do BC.

Os dados da DLSP escondem, no entanto, uma alteração radical na origem das fontes de crédito. Como pode ser comprovada pela Tabela 4, a DLSP interna,

(51) Não sabe a razão, mas há dois anos este valor era de 60,4\% do PIB e não consta que o PIB de 2002 tenha sido revisado desde 2015. 
que atingia o montante de 44,4\% do PIB em 2002, subiu continuamente até $61,3 \%$ do PIB em 2016. Ao final da série, a dívida líquida interna significava $133 \%$ da DLSP.

O caminho inverso foi trilhado pela DLSP externa que saiu, no mesmo período, de um montante de obrigações equivalente a 15,6\% do PIB, para uma posição credora de 15,3\% do PIB - uma variação de 30,9p.p. do PIB em 14 anos. Não foram apenas as RI, em forte movimento expansivo, que determinaram este comportamento, posto que outras dívidas (especialmente Clube de Paris, BIRD e BID) tiveram intensa retração: 15,7p.p. do PIB.

Tabela 4

DLSP interna e externa - 2002 a $2016 \mathrm{Em} \%$ do PIB (posição em dezembro)

\begin{tabular}{l|r|r|r|r|r|r|r|r|r|r|r|r|r|r|r}
\hline & $\mathbf{2 0 0 2}$ & $\mathbf{2 0 0 3}$ & $\mathbf{2 0 0 4}$ & $\mathbf{2 0 0 5}$ & $\mathbf{2 0 0 6}$ & $\mathbf{2 0 0 7}$ & $\mathbf{2 0 0 8}$ & $\mathbf{2 0 0 9}$ & $\mathbf{2 0 1 0}$ & $\mathbf{2 0 1 1}$ & $\mathbf{2 0 1 2}$ & $\mathbf{2 0 1 3}$ & $\mathbf{2 0 1 4}$ & $\mathbf{2 0 1 5}$ & $\mathbf{2 0 1 6}$ \\
\hline Dívida líquida total & 59,9 & 54,3 & 50,2 & 47,9 & 46,5 & 44,5 & 37,6 & 40,9 & 38,0 & 34,5 & 32,2 & 30,5 & 32,6 & 35,6 & 46,0 \\
\hline Dívida interna líquida & 44,4 & 43,2 & 42,4 & 44,8 & 47,6 & 51,8 & 48,3 & 49,7 & 47,2 & 46,8 & 45,1 & 43,9 & 46,2 & 54,8 & 61,3 \\
\hline Dívida externa líquida & 15,6 & 11,0 & 7,8 & 3,1 & $-1,2$ & $-7,3$ & $-10,7$ & $-8,8$ & $-9,3$ & $-12,3$ & $-12,9$ & $-13,4$ & $-13,6$ & $-19,2$ & $-15,3$ \\
\hline BCB (com Res. Intern.) & $-4,0$ & $-3,4$ & $-3,7$ & $-5,8$ & $-7,6$ & $-11,7$ & $-15,5$ & $-12,2$ & $-12,2$ & $-14,9$ & $-15,6$ & $-16,3$ & $-17,0$ & $-23,7$ & $-19,1$ \\
\hline Demais & 19,5 & 14,4 & 11,6 & 8,9 & 6,4 & 4,4 & 4,8 & 3,5 & 2,9 & 2,6 & 2,8 & 2,9 & 3,4 & 4,5 & 3,8 \\
\hline
\end{tabular}

Fonte: Elaboração própria a partir de dados do Banco de Dados do Site do BCB.

A constatação tem grande relevância do ponto de vista das relações de riqueza e posse de ativos na economia e especialmente das relações entre os agentes e a política fiscal. Como já apontado, a dívida interna traduz os movimentos de débito e crédito frente aos agentes que aceitam manter riqueza em moeda nacional ${ }^{52}$. $\mathrm{O}$ poder emissor implica maiores responsabilidades sobre o valor da moeda (e da riqueza) para o Estado. No caso das dívidas externas, os pagamentos não serão recebidos em moeda brasileira e, portanto, a condição de geração de dólares, e não de Reais, é que estará em causa para avaliação de risco dos credores externos.

Talvez o mais importante instrumento para entender a interação entre a macroeconomia e a DLSP seja a análise de seus fatores condicionantes. A Tabela 5 resume os dados publicados pelo $\mathrm{BC}$ e torna transparente a baixa relevância da questão fiscal num conceito que tem por objetivo justamente fazer sua mensuração. Os fatores que movem a dinâmica do estoque de dívidas públicas são diversos e fazem do superávit primário mero coadjuvante. O posicionamento da taxa de juros, o crescimento do PIB e a evolução cambial repercutem muito mais sobre a variação da dívida do que o próprio superávit primário.

Na maioria dos anos entre 2002 e 2016 nem seria necessário fazer superávits primários, dado que outros elementos que influem na dívida tiveram comportamento compensatório frente aos juros, mitigando o crescimento do quociente dívida/PIB. As duas últimas linhas da Tabela 4 mostram as relações entre o fator crescimento

(52) No caso dos swaps cambiais ofertados pelo BC, o pagamento é realizado em moeda nacional, embora indexado ao dólar, caso supere a variação do CDI. Por isso, o seu tratamento é como dívida interna. 
(fg), o fator juros nominais (fr) e o fator cambial (fe). Em 2004, 2008 e 2010, apenas o fator crescimento já teria superado ofator juros nominais.

Tabela 5

Fatores condicionantes da DLSP - 2002 a 2016 - Em \% do PIB

\begin{tabular}{l|c|c|c|c|c|c|c|c|c|c|c|c|c|c|c}
\hline & $\mathbf{2 0 0 2}$ & $\mathbf{2 0 0 3}$ & $\mathbf{2 0 0 4}$ & $\mathbf{2 0 0 5}$ & $\mathbf{2 0 0 6}$ & $\mathbf{2 0 0 7}$ & $\mathbf{2 0 0 8}$ & $\mathbf{2 0 0 9}$ & $\mathbf{2 0 1 0}$ & $\mathbf{2 0 1 1}$ & $\mathbf{2 0 1 2}$ & $\mathbf{2 0 1 3}$ & $\mathbf{2 0 1 4}$ & $\mathbf{2 0 1 5}$ & $\mathbf{2 0 1 6}$ \\
\hline Primário & $-3,19$ & $-3,24$ & $-3,69$ & $-3,74$ & $-3,15$ & $-3,24$ & $-3,33$ & $-1,94$ & $-2,62$ & $-2,94$ & $-2,18$ & $-1,71$ & 0,56 & 1,85 & 2,48 \\
\hline Juros Nominais & 7,61 & 8,42 & 6,56 & 7,28 & 6,72 & 5,98 & 5,32 & 5,13 & 5,03 & 5,41 & 4,44 & 4,67 & 5,39 & 8,36 & 6,47 \\
\hline Ajuste cambial - Dív Int & 5,15 & $-1,32$ & $-0,17$ & $-0,21$ & $-0,09$ & $-0,09$ & 0,10 & $-0,10$ & 0,04 & $-0,08$ & $-0,07$ & $-0,09$ & $-0,05$ & $-0,28$ & 0,07 \\
\hline Ajuste cambial - Dív Ext & 4,66 & $-2,47$ & $-0,73$ & $-0,72$ & $-0,18$ & 0,88 & $-2,62$ & 2,53 & 0,42 & $-1,44$ & $-1,11$ & $-1,71$ & $-1,61$ & $-6,15$ & 3,09 \\
\hline Dív Externa & 0,01 & 0,89 & 0,31 & $-0,06$ & 0,13 & $-0,08$ & $-0,85$ & 0,33 & 0,04 & $-0,21$ & $-0,10$ & 0,33 & 0,22 & 0,36 & $-0,03$ \\
\hline Cresc. do PIB & $-5,98$ & $-7,99$ & $-6,65$ & $-4,92$ & $-4,75$ & $-5,31$ & $-5,58$ & $-2,52$ & $-5,82$ & $-4,26$ & $-3,14$ & $-3,12$ & $-2,36$ & $-1,20$ & $-1,62$ \\
\hline Outros & 0,21 & 0,04 & 0,29 & 0,11 & $-0,10$ & $-0,07$ & $-0,02$ & $-0,11$ & 0,01 & 0,01 & $-0,12$ & $-0,06$ & $-0,06$ & 0,08 & $-0,05$ \\
\hline Variação da DLSP & 8,45 & $-5,68$ & $-4,07$ & $-2,27$ & $-1,43$ & $-1,94$ & $-6,98$ & 3,32 & $-2,91$ & $-3,51$ & $-2,28$ & $-1,69$ & 2,08 & 3,03 & 10,40 \\
\hline fg / fr & $-0,79$ & $-0,95$ & $-1,01$ & $-0,68$ & $-0,71$ & $-0,89$ & $-1,05$ & $-0,49$ & $-1,16$ & $-0,79$ & $-0,71$ & $-0,67$ & $-0,44$ & $-0,14$ & $-0,25$ \\
\hline (fg + fe) / fr & 0,50 & $-1,29$ & $-1,10$ & $-0,81$ & $-0,73$ & $-0,77$ & $-1,68$ & 0,05 & $-1,06$ & $-1,11$ & $-0,99$ & $-0,98$ & $-0,71$ & $-0,87$ & 0,23 \\
\hline Fonte: Elaboração própria a partir de dados do Banco de Dados do BCB.
\end{tabular}

Quando o ajuste cambial é incorporado à análise, as dúvidas sobre a necessidade de se fazer superávit primário são mais intensas. De 2002 a 2014, o efeito conjunto do crescimento com a valorização do Real representou mais de $70 \%$ do fator juros nominais, em 9 anos. Em 6 deles, a relação foi maior que 0,98. Ou seja, o superávit primário poderia ser muito inferior e ainda assim a dívida estaria estabilizada $^{53}$.

Efeitos completamente distintos tiveram os ajustes cambiais com a desvalorização do Real. Em 2002 e 2009, ajustes cambiais e dívida externa exerceram pressão expansionista sobre a DLSP, de 9,9\% e 2,8\% do PIB, respectivamente. Ou seja, os esforços fiscais foram incinerados pelo comportamento do câmbio. Note-se que a utilização da variação cambial num conceito de dívida que quer aferir o financiamento frente aos agentes que estão referidos à moeda nacional é bastante problemática ${ }^{54}$. Mas a observação é importante para que tenhamos presente a dimensão da ausência de conexão entre a teoria, os conceitos e instrumentos de medidas utilizados.

Os anos de 2015 e 2016 são particularmente esclarecedores. No primeiro, o ajuste cambial foi favorável ao endividamento em 6,2\% do PIB, dada a desvalorização do Real que afeta as RI, aumentando seu valor em Reais. Isto resultou em pequena variação da DLSP, mesmo com déficit primário e os juros nominais mais altos de toda a série. Em 2016, o câmbio mudou de sinal, e foi fator

(53) Em verdade, não consideramos esta questão relevante, porque seria muito mais adequado para a política econômica que as flutuações cambiais tivessem um tratamento muito mais refinado, mas a comparação é relevante, porque este é o estado das artes dos instrumentos de medida da política fiscal.

(54) Quando se avalia a variação da dívida interna, está em causa a moeda de emissão do Estado Nacional e, portanto, sua credibilidade está sendo monitorada pelos agentes econômicos. No caso da dívida externa, o poder emissor está fora do país e, por isso, nenhuma questão de solvência intertemporal pode ser colocada a partir da ação da política econômica interna. 
condicionante da elevação da DLSP em 3,1p.p. do PIB. Isto ocasionou a maior variação de dívida da série, mesmo com a soma de primário e juros nominais bem inferior à de 2015. O Gráfico 5 permite uma avaliação do impacto de questões cambiais na evolução da dívida.

Gráfico 5

Fatores condicionantes da DLSP - 2002 2016 - Em \% do PIB

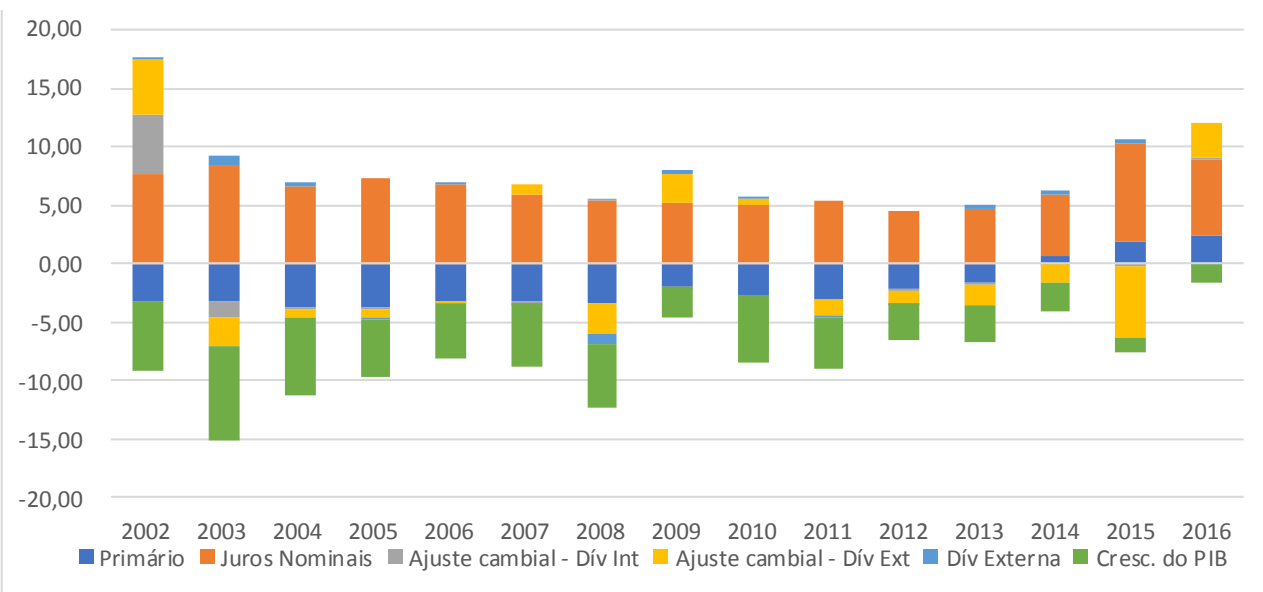

Fonte: BC. Elaboração própria.

É importante verificar também o conceito da Dívida Bruta do Governo Geral (DBGG), que passou a ser majoritariamente monitorado pelos analistas macroeconômicos a partir do descrédito na DLSP. Ele tem três diferenças essenciais com relação à DLSP: a) não contém as contas do $\mathrm{BC}$, o que isola as RI, embora considere suas operações compromissadas; $b$ ) compreende apenas as administrações governamentais, desconsiderando as empresas estatais; e c) considera todos os passivos, mas não desconta os ativos governamentais ${ }^{55}$.

A DBGG oscilou entre 50 e 55\% do PIB de 2006 a 2014. Foi no segundo semestre de 2014, quando se iniciou a retração da economia, que a dívida aumentou aceleradamente, saindo de 52,8\%, em jun./2014, para 69,6\% do PIB, em dez/2016. Dívida mobiliária e operações compromissadas do BC explicam 14,9p.p. dos 16,8p.p. do PIB da elevação, ou seja, a dinâmica financeira explica $90 \%$ da expansão da dívida bruta. Em contraposição, a soma dos déficits primários de 2015 e 2016 chega a 4,33\% do PIB. A desproporção dos efeitos real e financeiro mostra que a dinâmica das dívidas vai muito além do mero cotejamento entre receitas e despesas.

O avanço da dívida mobiliária e das operações compromissadas de quase 15p.p. do PIB em 30 meses não pode ser explicado apenas pela política fiscal,

(55) O conceito de DLSP é muito mais adequado para uma economia como a brasileira, de forte presença estatal, mas os problemas de coerência na sua mensuração minaram sua credibilidade. 
embora ela tenha sua parcela de contribuição. O fato é que as políticas de dívida mobiliária e gestão monetária do BC são, em primeira instância, a administração da riqueza social alocada em forma líquida, a diferentes prazos e instrumentos financeiros. Dadas as condições de desenvolvimento dos mercados de capitais no Brasil, são muito limitadas as ofertas de aplicação de recursos em passivos privados. Em condições normais, há uma convergência dos aplicadores para papeis emitidos pelo governo e por suas instituições. Na crise, a predominância das operações financeiras com o governo oferecendo passivos é absoluta, seja pela aversão ao risco dos aplicadores, seja pelo patamar de remuneração oferecido pelo Estado.

A questão aqui colocada é de grande relevância porque aponta uma falta de sintonia entre as políticas e seus indicadores. A evolução das dívidas, numa sociedade capitalista, atende a questões que vão muito além do fiscal, dado que câmbio, a gestão dos ativos e da liquidez são elementos centrais da administração das dívidas públicas. A falta de clareza sobre a política fiscal e sobre seus indicadores leva a políticas mal calibradas e a mais instabilidade.

\section{Considerações finais}

$\mathrm{O}$ artigo problematizou a formulação e a execução da política fiscal num capitalismo marcado pela financeirização e pelos grandes estoques de riqueza. Da contraposição à concepção do NCM, que neutraliza a política fiscal, negando-lhe função outra que não a de garantir a sustentabilidade da dívida pública, emerge a presença estatal ativa nas decisões econômicas, sempre entremeadas dos conflitos inerentes ao capitalismo. Da visão de que a política fiscal é executada numa economia monetária da produção, o Estado e suas contas ganham o protagonismo negado pela tese da moeda neutra.

Logicamente, os instrumentos da Golden Age keynesiana não poderiam gerir uma fase do capitalismo em que o processo de acumulação assume na riqueza financeira sua forma mais pujante. Mas o desenvolvimento de métodos para o Estado gerir a grande massa de ativos e garantir o processo de valorização do capital privado acaba anulando as outras formas de sua intervenção no processo de geração de riqueza material nova. De agente componente da demanda efetiva a ser definida em conjunto com os demais agentes de uma economia monetária da produção, o Estado, via política fiscal, passa a ser gestor da riqueza e garantidor da sua valorização.

O estado das artes no campo da política fiscal reflete a falta de clareza sobre as relações entre o Estado e o capitalismo financeirizado. Muito além de gerir receitas tributárias e despesas reais, a política fiscal tem que se deparar com a gestão dos estoques e de seus movimentos e remunerações. A gestão da liquidez, dos ativos e patrimônios, as arbitragens no mercado cambial, as políticas de crédito e subsídios, 
ganham dimensão e predominância nas contas públicas. Foi o que demonstramos com a avaliação do custo das RI, com a oferta de hedge via swaps e com a leitura dos fatores condicionantes da DLSP.

Se os conceitos de política fiscal, não são claros neste ambiente macroeconômico, as medidas das contas públicas tampouco seriam consistentes. Em verdade, NFSP é um híbrido entre o impacto financeiro e o real, onde o déficit operacional, que seria o mais relevante, nem mesmo é medido. Já no campo das medidas da dívida pública, bruta ou líquida, aspectos cambiais e de gestão de liquidez tornam estéril seu uso enquanto balizadoras da política fiscal. A magnitude dos estoques e a enorme variação dos seus preços (juros e câmbio) fazem dos indicadores utilizados meras variáveis residuais.

Analisar a política fiscal é, certamente, muito mais complexo quando movemos o foco de seu resultado, geralmente o primário, para sua substância: as enormes demandas colocadas sobre o Estado. Demandas que se expressam na forma de tributos, cobrados e não cobrados, e de gastos das mais variadas formas e naturezas. No entanto, a análise da política fiscal só será completa se ela refletir o movimento do Estado em sua interação dinâmica com a economia real e em suas relações com a renda e os estoques de riqueza.

\section{Bibliografia}

ALLSOPP, C.; VINES, D. The macroeconomic role of fiscal policy. Oxford Review of Economic Policy, v. 21, n. 4, p. 485-508, 2005.

ARESTIS, P. On the effectiveness of monetary policy. Annandale-On-Hudson, NY, Levy Economics Institute, 2003. (Working Paper, n. 369).

ARESTIS, P. What is the new consensus in macroeconomics? In: ARESIS, P. (Ed.). Is there a new consensus in macroeconomics? Basingstoke, Reino Unido: Palgrave MacMillan, 2007.

ARESTIS, P. New consensus macroeconomics and inflation targeting: a Keynesian critique. Economia e Sociedade, Campinas, v. 17, Número Especial, p. 629-653, 2008.

ARESTIS, P.; SAWYER, M. New consensus, new Keynesianism, and the economics of the third way. Annandale-On-Hudson, NY, Levy Economics Institute, 2002. (Working Paper, n. 364).

BACHA, E. Prólogo para a Terceira Carta. In: FÓRUM GAZETA MERCANTIL. FMI X Brasil: a armadilha da recessão. São Paulo: Gazeta Mercantil, 1983.

BARRO, R. Are government bonds net wealth? Journal of Political Economy, v. 82, n. 6, p. 1095-1117, 1974. 
BARRO, R.; GORDON, D. Rules, discretion and reputation in a model of monetary policy. Cambridge, MA, National Bureau of Economic Research, 1983. (Working Paper, n. 1079).

BELLUZZO, L. O declínio de Bretton Woods e a emergência dos mercados globalizados. Economia e Sociedade, Campinas, n. 4, 1995.

BIASOTO, G. A questão fiscal no contexto da crise do pacto desenvolvimentista. Tese (Doutorado)-Instituto de Economia. Universidade Estadual de Campinas (Unicamp), 1995.

BIASOTO, G. Sustentabilidade da dívida e superávit primário: restrições fiscais e financeiras ao desenvolvimento. In: CONGRESSO DA AKB, 9, Uberlândia, 2015. Anais...

BLANCHARD, O. Suggestions for a new set of fiscal indicators. Paris: OECD Economics Department, 1990. (Working Papers, n. 79).

BLEJER, M.; CHEASTY. A. The measurement of fiscal deficits: analytical and methodological issues. Journal of Economic Literature, v. 29, n. 4, p. 1644-1678, 1991.

BLINDER, A. The case against the case against discretionary fiscal policy. Princeton, NJ: Center for Economic Policy Studies, 2004. (Working Papers, n. 102).

BRAGA, J. A. Financeirização da riqueza. Economia e Sociedade, Campinas, v. 2, p. 25-58, 1993.

BRAGA, J. A. Temporalidade da riqueza: teoria da dinâmica e financeirização do capitalismo. Campinas: IE/Unicamp, 2000.

CARLIN, W.; SOSKICE, D. Macroeconomics: imperfections, institutions and policies. Oxford: Oxford University Press, 2006.

CARVALHO, F. Equilíbrio fiscal e política econômica keynesiana. Revista Análise Econômica, Porto Alegre, ano 26, n. 50, p. 7-25, 2008.

CHARI, V. V.; KEHOE, P. J.; MCGRATTAN, E. R. New Keynesian models: not yet useful for policy analysis. Cambridge: National Bureau of Economic Research, 2008. (Working Paper Series, n. 14313).

CLARIDA, R.; GALI, J.; GERTLER, M. The science of monetary policy: a new Keynesian perspective. Journal of Economic Literature, v. 37, n. 4, p. 1661-707, 1999.

COCHRANE, J. A frictionless view of U.S. inflation. Chicago: Center for Research in Security Prices, University of Chicago, 1998. (CRSP Working Papers, n. 479).

DAVIDSON, P. Money and the real world. London: MacMillan, 1978. 
DEVEREUX, M. Fiscal deficits, debt, and monetary policy in a liquidity trap. Dallas, Texas: Federal Reserve Bank of Dallas. Globalization and Monetary Policy Institute, 2010. (Working Paper, n. 44).

EPSTEIN, G. Financialization and the world economy: United Kingdom: Edward Elgar Publishing, 2005.

FOLHA DE SÃO PAULO - FSP. Bolsa fecha 2015 com terceiro maior fluxo de capital estrangeiro em 21 anos. 6 jan. 2016. Disponível em: http://www1.folha.uol.com.br/mercado/2016/01/1726440-bolsa-fecha-2015com-terceiro-maior-fluxo-de-capital-estrangeiro-em-21-anos.shtml. Acesso 30 out. 2017.

FONTANA, G. Whither new consensus macroeconomics? The role of government and fiscal policy in modern macroeconomics. Annandale-On-Hudson, NY, Levy Economics Institute, 2009. (Working Paper, n. 563).

FORDER, J. The historical place of the Friedman-Phelps. Expectation critique. Oxford: University of Oxford. Department of Economics, 2007. (Discussion Paper Series, n. 399).

FRIEDMAN, M. A monetary and fiscal framework for economic stability. The American Economic Review, Pittsburgh, PA, v. 38, n. 3, p. 245-264, 1948.

FRIEDMAN, M. The role of monetary policy. The American Economic Review, Pittsburgh, PA, v. 58, n. 1, p. 1-17, 1968.

FRIEDMAN, M.; HELLER, W. Monetary vs. fiscal policy. New York: W. W. Norton, 1969.

FUNDO MONETÁRIO INTERNACIONAL - FMI. Global Prospects and Policies. World Economic Outlook: Sustaining the recovery, p. i-66. 2009.

GOODFRIEND, M.; KING, R. The new neoclassical synthesis and the role of monetary policy. National Bureau of Economic Research Macroeconomics Annual, Cambridge, v. 12, p. 231-283, 1997.

HELLER, P. Considering IMF's perspective on a "sound fiscal policy". Washington, DC: International Monetary Fund, 2002. (Discussion Paper, n. 02/08).

JALORETTO, C. Seis décadas de déficit público no Brasil. Brasília: STN, 2009.

KEYNES, J. M. A treatise on money: the pure theory of money. In: THE COLLECTED writings of John Maynard Keynes, v. V. London: Macmillan, 1930 [1978].

KEYNES, J. M. The General Theory of Employment, Interest, and Money. New York: Harcourt-Brace \& World, Inc. 1936. 
KEYNES, J. M. Alternative theories of the rate of interest. Economic Journal, n. 47, p. 241-52, 1937.

KIRSANOVA, T.; STEHN, S.; VINES, D. The interactions between fiscal policy and monetary policy. Oxford Review of Economic Policy, v. 21, n. 4, p. 532-564, 2005.

KYDLAND, F.; PRESCOTT, E. Rules rather than discretion: the inconsistency of optimal plans. The Journal of Political Economy, v. 85, n. 3.p. 473-492, 1977.

LEEPER, E. Equilibria under "active" and "passive" monetary and fiscal policies. Journal of Monetary Economics, v. 27, n. 1, p. 129-147, 1991.

LEEPER, E.; WALKER, T. Perceptions and misperceptions of fiscal inflation. In: ALESINA, A.; GIAVAZZI, F. (Ed.). Fiscal policy after the financial crisis. National Bureau of Economic Research Conference Report, Chicago Press, 2013.

LOPREATO, F. Novos tempos. Política fiscal e condicionalidades pós-80. Revista de Economia Contemporânea, v. 8, n. 1, p. 125-154, 2004.

LOPREATO, F. O papel da política fiscal: um exame da visão convencional. Campinas: Unicamp. IE, 2006. (Texto para Discussão, n. 119).

MANTEGA, G. Rally contra o câmbio vai quebrar a cara porque nós temos US\$ 380 bilhões de reservas. Folha de São Paulo, Caderno de Economia, p. 1, 19 out. 2014.

MCCALLUM, B. Price level determinacy with an interest rate policy rule and rational expectations. Journal of Monetary Economics, v. 8, n. 3, p. 319-329, 1981.

MENDES, M. A Lei 11.803/2008 e a Relação Financeira Tesouro-Banco Central. Brasília: Senado Federal, 2016. (Textos para Discussão, n. 189).

MEYER, L. Does money matter? Federal Reserve Bank of St. Louis Review, v. 83, n. 5, p. 1-15, 2001.

PRATES, D.; BALTAR, C.; SEQUETO, M. A inserção externa do Brasil no contexto da crise global. In: NOVAIS, L.; CAGNIN, R.; BIASOTO, G. (Org.). A economia brasileira no contexto da crise global. São Paulo: Edições Fundap, 2014. p. 79-122.

REINHART, C.; ROGOFF, K. Growth in a time of debt. American Economic Association Papers and Proceedings, v. 100, n. 2, p. 573-578, 2010.

SALTO, F.; AFONSO, J. R.; BIASOTO, G.; KOHLER, M. As duas dimensões do ajuste fiscal. In: BACHA, E. (Org.). A crise fiscal e monetária brasileira. Rio de Janeiro: Civilização Brasileira, 2016. p. 467-480. 
SARGENT, T.; WALLACE, N. Some unpleasant monetarist arithmetic. Federal Reserve Bank of Minneapolis Quarterly Review, 1981.

SANTOS, F. A nova síntese neoclássica frente à crise econômica mundial: a volta da política fiscal? Dissertação (Mestrado)-Instituto de Economia. Universidade Estadual de Campinas, Campinas, 2011.

SOLOW, R. Rethinking fiscal policy. Oxford Review of Economic Policy, v. 21, n. 4, p. 509-514, 2005.

TAVARES, M.; MELIN, L. Pós-escrito 1997: a reafirmação da hegemonia norteamericana. In: TAVARES, M.; FIORI, J. (Org.). Poder e dinheiro. Uma economia política da globalização. Rio de Janeiro: Ed. Vozes, 1997. p. 55-86.

TAYLOR, J. Discretion versus policy rules in practice. Carnegie-Rochester Conference Series on Public Policy, v. 39, n. 1, p. 195-214, 1993.

TCHERNEVA, P. The return of fiscal policy: can the new developments in the new economic consensus be reconciled with the post-Keynesian view? Annandale-OnHudson, NY, Levy Economics Institute, 2008. (Working Paper, n. 539).

WREN-LEWIS, S. The limits to discretionary fiscal stabilization policy. Oxford Review of Economic Policy, v. 16, n. 4, p. 92-115, 2000.

WOODFORD, M. Public debt and the price level. Princeton, NJ: Princeton University, 1998. (Working Paper).

WOODFORD, M. Interest and prices: foundations of a theory of monetary policy. Princeton, NJ: Princeton University Press, 2003.

WOODFORD, M. Convergence in macroeconomics: elements of the new synthesis. American Economic Journal: Macroeconomics, v. 1, n. 1, p. 267-279, 2008. 